\title{
Multimethod U-Pb baddeleyite dating: insights from the Spread Eagle Intrusive Complex and Cape St. Mary's sills, Newfoundland, Canada
}

\author{
Johannes E. Pohlner ${ }^{1,2}$, Axel K. Schmitt ${ }^{1}$, Kevin R. Chamberlain ${ }^{3,4}$, Joshua H. F. L. Davies ${ }^{5,6}$, Anne Hildenbrand ${ }^{1}$, \\ and Gregor Austermann ${ }^{1}$ \\ ${ }^{1}$ Institut für Geowissenschaften, Universität Heidelberg, Im Neuenheimer Feld 234-236, 69120 Heidelberg, Germany \\ ${ }^{2}$ Unit of Earth Sciences, Department of Geosciences, University of Fribourg, Chemin du Musée 6, 1700 Fribourg, Switzerland \\ ${ }^{3}$ Department of Geology and Geophysics, University of Wyoming, 1000 E. University Ave., Laramie, WY 82071-2000, USA \\ ${ }^{4}$ Faculty of Geology and Geography, Tomsk State University, Tomsk 634050, Russia \\ ${ }^{5}$ Department of Earth and Atmospheric Sciences, Université du Québec à Montréal, 201, \\ Avenue du Président Kennedy, H2X 3Y7, Montréal, QC, Canada \\ ${ }^{6}$ Department of Earth Sciences, University of Geneva, Rue des Maraîchers 13, 1205 Geneva, Switzerland
}

Correspondence: Johannes E. Pohlner (johannes.pohlner@unifr.ch)

Received: 16 December 2019 - Discussion started: 29 January 2020

Revised: 27 May 2020 - Accepted: 17 June 2020 - Published: 8 July 2020

\begin{abstract}
Baddeleyite $\left(\mathrm{ZrO}_{2}\right)$ is widely used in $\mathrm{U}-\mathrm{Pb}$ geochronology but analysis and age interpretation are often difficult, especially for samples which have experienced post-intrusive alteration and/or metamorphism. Here, we combine high spatial resolution (secondary ionization mass spectrometry, SIMS) and high-precision (isotope dilution thermal ionization mass spectrometry, ID-TIMS) analyses of baddeleyite from the Spread Eagle Intrusive Complex (SEIC) and Cape St. Mary's sills (CSMS) from Newfoundland. Literature data and our own detailed microtextural analysis suggest that at least seven different types of baddeleyite-zircon intergrowths can be distinguished in nature. These include secondary baddeleyite inclusions in altered zircon, previously unreported from low-grade rocks, and likely the first discovery of xenocrystic zircon inclusions mantled by baddeleyite. ${ }^{207} \mathrm{~Pb} /{ }^{206} \mathrm{~Pb}$ baddeleyite dates from SIMS and IDTIMS mostly overlap within uncertainties. However, some SIMS sessions of grain mounts show reverse discordance, suggesting that bias in the $\mathrm{U} / \mathrm{Pb}$ relative sensitivity calibration affected ${ }^{206} \mathrm{~Pb} /{ }^{238} \mathrm{U}$ dates, possibly due to crystal orientation effects, and/or alteration of baddeleyite crystals, which is indicated by unusually high common- $\mathrm{Pb}$ contents. ID-TIMS data for SEIC and CSMS single baddeleyite crystals reveal normal discordance as linear arrays with decreasing ${ }^{206} \mathrm{~Pb} /{ }^{238} \mathrm{U}$ dates, indicating that their discordance
\end{abstract}

is dominated by recent $\mathrm{Pb}$ loss due to fast pathway diffusion or volume diffusion. Hence, ${ }^{207} \mathrm{~Pb} /{ }^{206} \mathrm{~Pb}$ dates are more reliable than ${ }^{206} \mathrm{~Pb} /{ }^{238} \mathrm{U}$ dates even for Phanerozoic baddeleyite. Negative lower intercepts of baddeleyite discordia trends for ID-TIMS dates for SEIC and CSMS and direct correlations between ID-TIMS ${ }^{207} \mathrm{~Pb} /{ }^{206} \mathrm{~Pb}$ dates and the degree of discordance may indicate preferential ${ }^{206} \mathrm{~Pb}$ loss, possibly due to ${ }^{222} \mathrm{Rn}$ mobilization. In such cases, the most reliable crystallization ages are concordia upper intercept dates or weighted means of the least discordant ${ }^{207} \mathrm{~Pb} /{ }^{206} \mathrm{~Pb}$ dates.

We regard the best estimates of the intrusion ages to be $498.7 \pm 4.5 \mathrm{Ma}(2 \sigma$; ID-TIMS upper intercept date for one SEIC dike) and $439.4 \pm 0.8 \mathrm{Ma}$ (ID-TIMS weighted mean ${ }^{207} \mathrm{~Pb} /{ }^{206} \mathrm{~Pb}$ date for one sill of CSMS). This first radiometric age for the SEIC is consistent with stratigraphic constraints and indicates a magmatic episode prior to opening of the Rheic Ocean. Sample SL18 of the Freetown Layered Complex (FLC), Sierra Leone, was investigated as an additional reference. For SL18, we report a revised $201.07 \pm 0.64 \mathrm{Ma}$ intrusion age, based on a weighted mean ${ }^{207} \mathrm{~Pb} /{ }^{206} \mathrm{~Pb}$ date of previous and new baddeleyite ID-TIMS data, agreeing well with corresponding SIMS data. Increasing discordance with decreasing crystal size in SL18 indicates that $\mathrm{Pb}$ loss affected baddeleyite rims more strongly than cores. Our SL18 results validate that the SIMS in situ 
approach, previously used for Precambrian and Paleozoic samples, is also suitable for Mesozoic baddeleyite.

\section{Introduction}

Baddeleyite, a monoclinic $\mathrm{ZrO}_{2}$ polymorph, is one of the most commonly used minerals in $\mathrm{U}-\mathrm{Pb}$ geochronology, especially for mafic rocks, which are traditionally difficult to date (e.g., Schaltegger and Davies, 2017). It forms most readily during the late stage of igneous crystallization from a silicaundersaturated residual melt and can coexist with zircon at conditions near silica saturation (Heaman and LeCheminant, 1993; Schaltegger and Davies, 2017). Where both minerals coexist, geochronologists have tended to prefer baddeleyite dates because it is (1) a primary igneous mineral, facilitating age interpretation; (2) rarely inherited from country rock; and (3) more resistant to $\mathrm{Pb}$ loss compared to zircon (e.g., Heaman and LeCheminant, 1993), as it remains crystalline even at high radiation doses (Lumpkin, 1999). U-Pb baddeleyite dating has proved powerful in solving numerous problems in earth and planetary sciences (e.g., Olsson et al., 2011; Moser et al., 2013; Wall and Scoates, 2016; Davies et al., 2017; White et al., 2020).

However, many of these studies were able to work with rather large, texturally simple, unaltered and concordant baddeleyite crystals. Such favorable conditions are the exception rather than the rule for large parts of the geologic record. In fact, crystals are often too small for mineral separation (Söderlund and Johansson, 2002), prohibiting high-precision ID-TIMS (isotope dilution-thermal ionization mass spectrometry) analysis. Instead, they can be analyzed in situ by secondary ionization mass spectrometry (SIMS; e.g., Schmitt et al., 2010; Chamberlain et al., 2010) or laser ablation inductively coupled plasma mass spectrometry (LA-ICP-MS; e.g., Renna et al., 2011). In situ methods require relative sensitivity corrections, which may be complicated by crystal orientation effects (Wingate and Compston, 2000), although these effects for SIMS can be reduced by oxygen flooding (Schmitt et al., 2010; Li et al., 2010). Furthermore, baddeleyite can be intergrown with other Zr-bearing minerals, especially in rocks with a metamorphic or hydrothermal overprint, where fluids with high $\mathrm{SiO}_{2}$ activity often cause partial reaction of baddeleyite to polycrystalline zircon (Heaman and LeCheminant, 1993; Söderlund et al., 2013). In situ dating after careful micropetrographic investigation can resolve such intergrowths, and for ID-TIMS, baddeleyite can be selectively dissolved in hydrochloric acid, leaving zircon rims essentially undissolved (Rioux et al., 2010). However, even baddeleyite that lacks zircon intergrowths is often discordant and chemical abrasion, which is now routinely used to produce more concordant zircon data, is ineffective for reducing baddeleyite discordance (Rioux et al., 2010). Mechanisms such as alpha recoil (Davis and Sutcliffe, 1985; Davis and Davis, 2018), Pb loss due to fast pathway diffusion (Rioux et al.,
2010; Söderlund et al., 2013; Schaltegger and Davies, 2017), and isotopic disequilibrium due to ${ }^{231} \mathrm{~Pa}$ excess (Amelin and Zaitsev, 2002; Crowley and Schmitz, 2009) or ${ }^{222} \mathrm{Rn}$ loss (Heaman and LeCheminant, 2000) have been proposed to explain baddeleyite discordance, but none of these are universally accepted as the dominant baddeleyite discordance mechanism.

It is necessary to investigate to which degree reliable baddeleyite dating is possible when several of the abovementioned challenges come together. Here, we present a case study of dating the Spread Eagle Intrusive Complex (SEIC) and Cape St. Mary's sills (CSMS) of the Avalon Zone of Newfoundland. These early Paleozoic mafic dikes and sills were affected by low-grade metamorphism and contain abundant texturally complex baddeleyite, as commonly found in the geologic record. Moreover, the approximate intrusion age of the SEIC is constrained by its stratigraphic context. We applied U-Pb geochronology by SIMS and ID-TIMS on the same baddeleyite crystals, combined with detailed micropetrographic characterization of baddeleyite by scanning electron microscopy (SEM) before and after SIMS analysis. Our comparison of SIMS and ID-TIMS dating also includes essentially unaltered baddeleyite from the Duluth gabbro (sample FC-4b; Schmitt et al., 2010) and Freetown Layered Complex (sample SL18; Callegaro et al., 2017), leading to a critical evaluation of possibilities and limitations in dating small, texturally complex and/or altered baddeleyite crystals. Based on our micropetrographic and geochronologic data, we discuss various types of baddeleyite-zircon intergrowths, possible mechanisms of baddeleyite discordance and the reliability of different types of baddeleyite dates (e.g. ${ }^{206} \mathrm{~Pb} /{ }^{238} \mathrm{U}$, ${ }^{207} \mathrm{~Pb} /{ }^{206} \mathrm{~Pb}$, concordia upper intercept). Many of these implications are also significant for unaltered baddeleyite.

\section{Regional geology}

The Avalon Peninsula consists of rocks that were formed as part of the microcontinent Avalonia during the Neoproterozoic and early Paleozoic (e.g., Williams, 1979; Murphy et al., 1999; Fig. 1). The Cambrian Adeyton and Harcourt groups (Hutchinson, 1962; King, 1988; Fig. 2), which unconformably overlie Precambrian rocks, consist of wellpreserved marine sediments with intercalated pillow basalts and mafic tuffs. The feeder pipes or dike-like conduits of these volcanic rocks make up a mafic intrusive complex, called the "Spread Eagle Gabbro" (McCartney, 1967) or "Spread Eagle Gabbro and equivalents" (King, 1988). To avoid confusion, we define this unit, consisting of at least 11 dikes, as the Spread Eagle Intrusive Complex (SEIC). Lower Ordovician sedimentary rocks are exposed only on Conception Bay islands northeast of the study area (King, 1988). They are roughly coeval with Avalonia's presumably early Ordovician separation from Gondwana (e.g., Cocks et al., 1997; Murphy et al., 2006; Linnemann et al., 2008, 2012; 


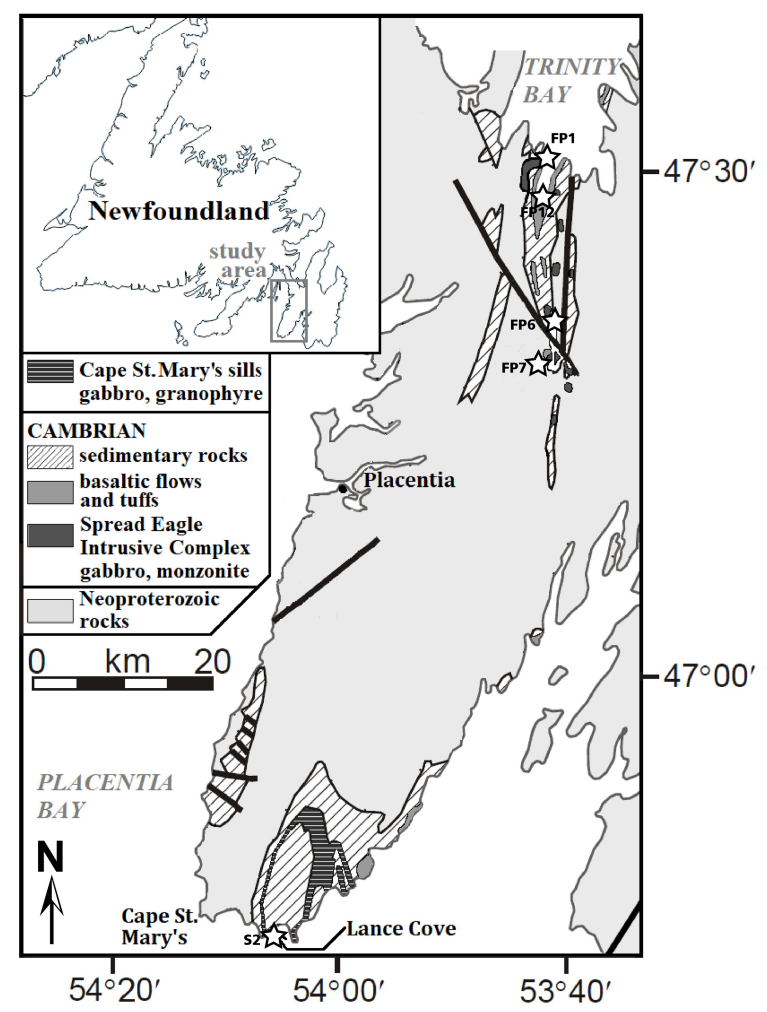

Figure 1. Simplified geological map of the western Avalon Peninsula, compiled after King (1988) and O’Brien et al. (2001).

Pollock et al., 2009, 2012). The Cambrian pillow basalts and their feeder dikes are confined to the western Avalon Peninsula, which experienced deformation and pervasive lowgrade metamorphism during the Acadian Orogeny (McCartney, 1967), lasting from ca. 420 to $360 \mathrm{Ma}$ (van Staal and Barr, 2012; Willner et al., 2014).

\subsection{Spread Eagle Intrusive Complex (SEIC) and Cambrian volcanic rocks}

Cambrian shales of the Chamberlain's Brook Formation and Manuels River Formation contain pillow basalt flows and/or basaltic metatuffs in five different localities (McCartney, 1967; Greenough, 1984; Greenough and Papezik, 1985b; Fletcher, 2006). Additionally, our field observations suggest their presence also within the overlying Elliot Cove formation (sensu stricto King, 1988). Several lines of indirect field evidence substantiate that these volcanic rocks were fed by the SEIC dikes or pipes which crop out in their vicinity (Greenough, 1984; Greenough and Papezik, 1985b). The SEIC intrusions are arranged in a N-S-trending array (Fig. 1) and are usually subcircular pipes with diameters of several hundreds of meters (McCartney, 1967). Petrologically, they are internally differentiated, ranging from melanogabbros to leucogabbros (Greenough, 1984; Greenough and Papezik, 1985b) and monzonites (this study). These subvolcanic rocks

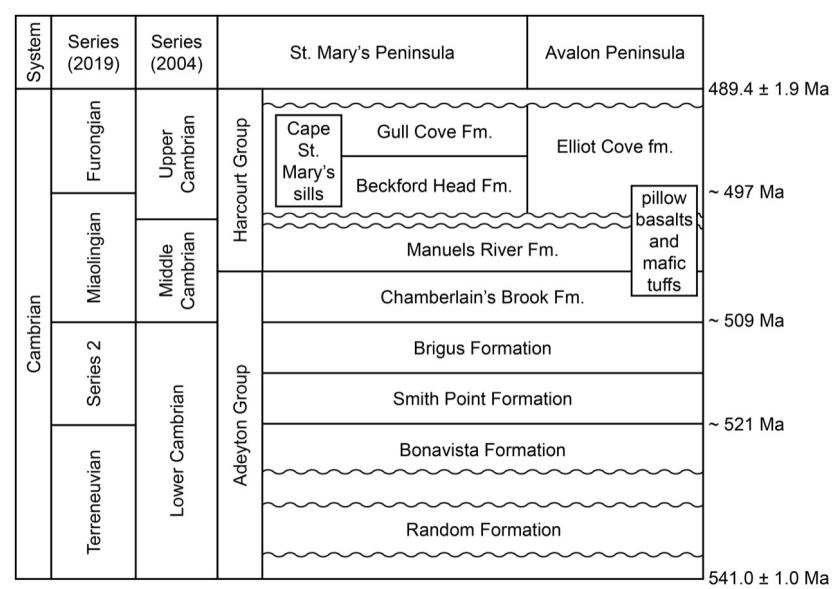

Figure 2. Cambrian stratigraphy of the western Avalon Peninsula, compiled after King (1988), Fletcher (2006) and Austermann (2016). Subdivision of the Cambrian after Peng et al. (2012).

are considerably altered to a greenschist facies assemblage but better preserved than the volcanic rocks, which almost completely lack primary minerals (Greenough and Papezik, 1985a, b). Geochemical features of the SEIC rocks are similar to rift basalts, suggesting that Avalonia experienced extensional tectonics in the Cambrian (Greenough and Papezik, 1985b; Greenough and Papezik, 1986a; new whole-rock major and trace-element data are given in the Sect. S7). Early attempts at radiometric dating of the SEIC failed, as alteration hampered $\mathrm{Rb}-\mathrm{Sr}$ whole-rock methods and zircons were not found (Greenough, 1984). Samples of the current study were collected from several SEIC feeder pipes (Table 1).

\subsection{Cape St. Mary's sills (CSMS)}

In addition to the occurrence of the Cambrian igneous rocks described above, the Cambrian succession is intruded by the CSMS in the southwestern Avalon Peninsula, especially in the upper Cambrian Gull Cove Formation (Fletcher, 2006). The sills are up to $60 \mathrm{~m}$ thick and consist mostly of gabbro, but the thickest sills also include up to $3 \mathrm{~m}$ thick granophyric dikes and pockets (Greenough and Papezik, 1986b; Fletcher, 2006). The gabbros and granophyres are both unusually rich in hydrous minerals, notably amphibole and biotite, and volatile complexing was probably an important differentiation process of the subalkaline parental magma (Greenough and Papezik, 1986b). Trace-element patterns indicate that the magma was generated from a mantle source that had been metasomatically enriched by subduction-zonederived fluids (Greenough et al., 1993; this study, Supplement Sect. S7). A CSMS granophyre was the first terrestrial rock for which baddeleyite dating was performed (Greenough, 1984 and John D. Greenough, personal communication, 2019). These ID-TIMS analyses of multiplecrystal aliquots yielded an early Silurian weighted mean 
Table 1. Samples used for U-Pb geochronology.

\begin{tabular}{|c|c|c|c|c|c|c|c|c|}
\hline \multirow[t]{2}{*}{ Unit } & \multirow[t]{2}{*}{ Sample } & \multirow[t]{2}{*}{ Coordinates } & \multirow[t]{2}{*}{ Rock type } & \multicolumn{2}{|c|}{ Typical crystal size $(\mu \mathrm{m})$} & \multicolumn{2}{|c|}{ SIMS } & \multirow[t]{2}{*}{ ID-TIMS } \\
\hline & & & & Baddeleyite & Zircon & In situ & Grain mount & \\
\hline \multirow[t]{3}{*}{ SEIC } & FP6D & $\begin{array}{l}47^{\circ} 22.004^{\prime} \mathrm{N}, \\
053^{\circ} 39.802^{\prime} \mathrm{W}\end{array}$ & $\begin{array}{l}\text { Pegmatoidal } \\
\text { monzonite }\end{array}$ & $50-200$ & 50 & & $\mathrm{X}$ & $\mathrm{X}$ \\
\hline & FP7G & $\begin{array}{l}47^{\circ} 22.098^{\prime} \mathrm{N}, \\
053^{\circ} 39.178^{\prime} \mathrm{W}\end{array}$ & Monzogabbro & $5-30$ & $5-10$ & $\mathrm{X}$ & & \\
\hline & FP12A & $\begin{array}{l}47^{\circ} 31.274^{\prime} \mathrm{N}, \\
053^{\circ} 39.259^{\prime} \mathrm{W}\end{array}$ & Gabbro & $10-30$ & $5-10$ & $\mathrm{X}$ & & \\
\hline \multirow[t]{2}{*}{ CSMS } & $\mathrm{S} 2 \mathrm{C}$ & $\begin{array}{l}46^{\circ} 47.756^{\prime} \mathrm{N}, \\
054^{\circ} 05.866^{\prime} \mathrm{W}\end{array}$ & Granophyre & $\begin{array}{r}\text { Inclusions } \\
\text { in zircon }\end{array}$ & $20-200$ & $\mathrm{X}$ & & \\
\hline & S2E & $\begin{array}{l}46^{\circ} 47.756^{\prime} \mathrm{N}, \\
054^{\circ} 05.866^{\prime} \mathrm{W}\end{array}$ & Granophyre & $5-200$ & $50-200$ & $X$ & $X$ & $X$ \\
\hline $\begin{array}{l}\text { Duluth } \\
\text { gabbro }\end{array}$ & FC-4b & $\begin{array}{l}47^{\circ} 46.118^{\prime} \mathrm{N}, \\
091^{\circ} 21.402^{\prime} \mathrm{W}\end{array}$ & $\begin{array}{l}\text { Gabbroic } \\
\text { anorthosite }\end{array}$ & $100-200$ & $100-200$ & $\mathrm{X}$ & & $\mathrm{X}^{*}$ \\
\hline FLC & SL18 & $\begin{array}{l}08^{\circ} 27^{\prime} \mathrm{N}, \\
13^{\circ} 13^{\prime} \mathrm{W}\end{array}$ & $\begin{array}{l}\text { Olivine gab- } \\
\text { bronorite }\end{array}$ & tens to hundreds & - & $\mathrm{X}$ & $\mathrm{X}$ & $\mathrm{X}^{*}$ \\
\hline
\end{tabular}

* ID-TIMS data for FC-4b are from Schmitt et al. (2010); those for SL18 are partly from Callegaro et al. (2017).

${ }^{207} \mathrm{~Pb} /{ }^{206} \mathrm{~Pb}$ date of $441 \pm 2 \mathrm{Ma}$, but all analyses are discordant to $2.0 \%-3.5 \%$ (Greenough et al., 1993). Combining this date with a paleolatitude of $32^{\circ} \mathrm{S} \pm 8^{\circ}$, the CSMS was interpreted as the result of an igneous event after Avalonia's separation from Gondwana but before complete closure of the Iapetus Ocean (Hodych and Buchan, 1998). Samples of the current study were collected from a $60 \mathrm{~m}$ thick sill at the southwestern coast of Lance Cove (Table 1) from the same sill as in Greenough et al. (1993).

\section{$3 \mathrm{U}-\mathrm{Pb}$ geochronology methods}

Care was taken during field work to collect samples as coarse-grained and unaltered as possible. Such samples are most likely to yield large high-quality baddeleyite crystals, as baddeleyite typically forms in interstitial melt pockets and can react to zircon in response to Si-bearing metamorphic fluids (Heaman and LeCheminant, 1993). Polished thin sections of selected samples were investigated by SEM (backscattered electron (BSE) and cathodoluminescence (CL) imaging and energy dispersive X-ray spectrometry (EDS)) to localize baddeleyite and study its textural properties. When baddeleyite and/or zircon crystals were too small for mineral separation $(<50 \mu \mathrm{m})$, they were analyzed in situ in thin section by SIMS for U-Pb dates (Table 1). For samples with larger crystals, polished epoxy grain mounts were prepared from handpicked separates, followed by SEM imaging and SIMS analysis. Every SIMS session was followed by re-imaging of the analysis craters by SEM to identify analyses with contributions from adjacent phases (see
Supplement Sect. S1). Selected crystals were removed from grain mounts for single-crystal ID-TIMS analyses.

SIMS analyses were performed using a CAMECA ims 1280-HR ion probe at Heidelberg University. Oxygen flooding of the sample chamber was employed to mitigate crystal orientation effects and improve secondary ion yields (Schmitt et al., 2010; Chamberlain et al., 2010; Li et al., 2010 ), using oxygen pressures of $2.0-3.0 \times 10^{-3} \mathrm{~Pa}$. The primary ion beam was focused to a diameter of about $10-15 \mu \mathrm{m}$. In cases where an even higher spatial resolution was needed, the field aperture of the secondary beam was closed to a square of 5-8 $\mu \mathrm{m}$. Analytical procedures for baddeleyite and zircon were adapted from Schmitt et al. (2010). The U/Pb relative sensitivity calibration (RSC) against the $\mathrm{UO}_{2} / \mathrm{U}$ ratio accounts for differences in $\mathrm{Pb}$ ionization caused by spot-tospot differences in sputtering behavior. For this, Phalaborwa baddeleyite (Heaman, 2009) was always used as primary reference material. For grain mount sessions, FC-4b baddeleyite (Schmitt et al., 2010) was included as secondary reference material. Zircon analyses were calibrated using the reference materials AS3 (Schmitz et al., 2003) for U-Pb ages and 91500 (Wiedenbeck et al., 2004) for U concentrations. Zirconolite from sample FP7G was analyzed to investigate the influence of its matrix on $\mathrm{U}-\mathrm{Pb}$ baddeleyite dates when the primary ion beam overlaps onto both minerals.

For ID-TIMS analyses of samples FP6D and S2E, baddeleyite dissolution and chemistry were adapted from Rioux et al. (2010). Baddeleyite crystals were plucked from the SIMS grain mount, spiked with a mixed ${ }^{205} \mathrm{~Pb} /{ }^{233} \mathrm{U} /{ }^{235} \mathrm{U}$ tracer (ET535) and dissolved in $\mathrm{HCl}$ acid. Solutions were pipetted 
into beakers to separate them from undissolved zircon domains. $\mathrm{Pb}$ and $\mathrm{UO}_{2}$ from baddeleyite were loaded onto single rhenium filaments with silica gel without ion exchange cleanup. Isotopic compositions were measured on a Micromass Sector 54 TIMS at the University of Wyoming in single Daly photomultiplier mode. The model of Stacey and Kramers (1975) at $400 \mathrm{Ma}$ was used for common-Pb corrections of SIMS and ID-TIMS analyses. The decay constants and ${ }^{238} \mathrm{U} /{ }^{235} \mathrm{U}$ ratio are from Steiger and Jäger (1977). Concordia coordinates and uncertainties were calculated using IsoplotR for SIMS (Vermeesch, 2018) and PBMacDAT and IsoplotEX for ID-TIMS (Ludwig, 1988, 2003).

\section{Secondary reference baddeleyite from the Duluth gabbro and Freetown Layered Complex (FLC)}

Reference baddeleyite FC-4b is from the anorthositic series of the Duluth Complex, part of the middle Proterozoic (ca. 1.1 Ga) North American Midcontinent Rift system (Paces and Miller, 1993). This sample from the anorthositic series of the complex is described as an olivine-phyric gabbroic anorthosite (Hoaglund, 2010). FC-4b baddeleyite has yielded dates of $1096.84 \pm 0.45 \mathrm{Ma}\left({ }^{206} \mathrm{~Pb} /{ }^{238} \mathrm{U}\right.$; all uncertainties quoted in the text are $2 \sigma$ ) and $1099.6 \pm 1.5 \mathrm{Ma}$ $\left({ }^{207} \mathrm{~Pb} /{ }^{206} \mathrm{~Pb}\right)$ by ID-TIMS analysis (Schmitt et al., 2010). Our new SIMS data for FC-4b are from baddeleyite crystals with petrographic properties comparable to those of Schmitt et al. (2010).

Sample SL18 is an olivine gabbronorite from the Freetown Layered Complex (FLC) in Sierra Leone, which is part of the Central Atlantic Magmatic Province (CAMP). SL18 consists of plagioclase and augite with minor olivine and accessory baddeleyite and apatite. Large baddeleyite crystals (with $\mathrm{U}$ contents of $1-4 \mathrm{ng}$ ) produced a weighted mean ${ }^{206} \mathrm{~Pb}-{ }^{238} \mathrm{U}$ date of $198.777 \pm 0.047 \mathrm{Ma}$ by ID-TIMS (Callegaro et al., 2017). However, these data show some scatter and the mean date was generated by 7 out of a total of 11 analyses and is still significantly younger than all zircon U-Pb ID-TIMS dates from CAMP samples (Blackburn et al., 2013; Davies et al., 2017) at $\sim 201.5 \mathrm{Ma}$. However, the ${ }^{207} \mathrm{~Pb} /{ }^{206} \mathrm{~Pb}$ date for SL18 is $201.19 \pm 0.69 \mathrm{Ma}$, overlapping with Ar-Ar dates from FLC and $\mathrm{U}-\mathrm{Pb}$ dates from CAMP samples throughout different localities. The young and slightly scattered ${ }^{206} \mathrm{~Pb}-{ }^{238} \mathrm{U}$ date with an older "CAMP"-type ${ }^{207} \mathrm{~Pb} /{ }^{206} \mathrm{~Pb}$ age suggests that SL18 baddeleyite may have been affected by $\mathrm{Pb}$ loss. Callegaro et al. (2017) discussed different age interpretations of SL18 extensively but were unfortunately unable to determine a robust $\mathrm{U}-\mathrm{Pb}$ crystallization age. We present additional single-crystal ID-TIMS data of SL18, obtained with exactly the same methodology as for Callegaro et al. (2017) at the University of Geneva (details in Sect. S2) but with baddeleyite crystals from the same separate that are 10-30 times smaller.

\section{Petrography}

\subsection{Spread Eagle Intrusive Complex (SEIC)}

The SEIC rocks have well-preserved igneous textures, but major and accessory minerals are frequently replaced by parageneses indicative of alteration and low-grade metamorphism. Grain size and color index can vary considerably, ranging from fine-grained melanogabbros to coarser-grained rarely pegmatoidal monzonites and monzosyenites. Plagioclase is always completely altered to albite. Many samples also contain large amounts of K-feldspar. In the less potassic samples, K-feldspar is concentrated in interstitial areas or leucocratic pockets, often together with accessory minerals. Minor quartz is often present in baddeleyite-bearing and baddeleyite-free rocks but usually in secondary pockets and veins. Clinopyroxene is replaced by chlorite to a variable extent, often as pseudomorphs. Some samples have essentially unaltered clinopyroxene but also contain chlorite pseudomorphs. Ilmenite is largely replaced by titanite \pm rutile \pm magnetite. Other common secondary minerals are calcite, epidote, prehnite and/or pumpellyite, as well as accessory sulfides (pyrite, chalcopyrite, galena, sphalerite). Apatite is ubiquitous.

All samples contain Zr-bearing accessory phases. Baddeleyite occurs in many samples, usually as $<20 \mu \mathrm{m}$ long, lathshaped euhedral crystals. Crystals $20-80 \mu \mathrm{m}$ in length occasionally occur in some samples, and FP6D is the only sample with large $(50-200 \mu \mathrm{m})$ baddeleyite crystals (Fig. 3bd). SEIC baddeleyite is commonly intergrown with zircon, forming a variety of textures. The most common case is that baddeleyite crystals contain zircon domains mostly at their rim but commonly penetrating into the core. This largely pseudomorphic replacement texture is accompanied by feather-like zircon coronas around the crystal (e.g., Fig. 4d). Baddeleyite preservation tends to be better if the rock is less altered but also if crystals are large, as the presence of rather modest zircon overgrowths in the strongly altered monzonite FP6D indicates. Baddeleyite inclusions in $\mathrm{K}$-feldspar usually lack zircon intergrowths. In samples FP1F and FP1I, clusters of baddeleyite needles are enclosed by zircon crystals (Fig. 3a). The enclosing zircon is sometimes almost euhedral but often with feather-like zircon overgrowths. A special feature we identified in FP12A is that some baddeleyite crystals have zircon inclusions up to $3 \mu \mathrm{m}$ wide and at most $12 \mu \mathrm{m}$ long (Fig. 4f-k). Secondary zircon overgrowth on the enclosing baddeleyite was rarely observed. Besides that, FP12A contains prismatic euhedral baddeleyite crystals essentially free of zircon but with a notch on one prism plane that penetrates into the crystal's core (Fig. 4e, 1). Zircon crystals without baddeleyite intergrowth are sometimes present also in baddeleyite-bearing rocks. Some of these crystals have an amoeboid surface and a scarred interior. Baddeleyitefree rocks are often either melanocratic or rich in quartz. They contain zircon as the only Zr-bearing mineral, forming 

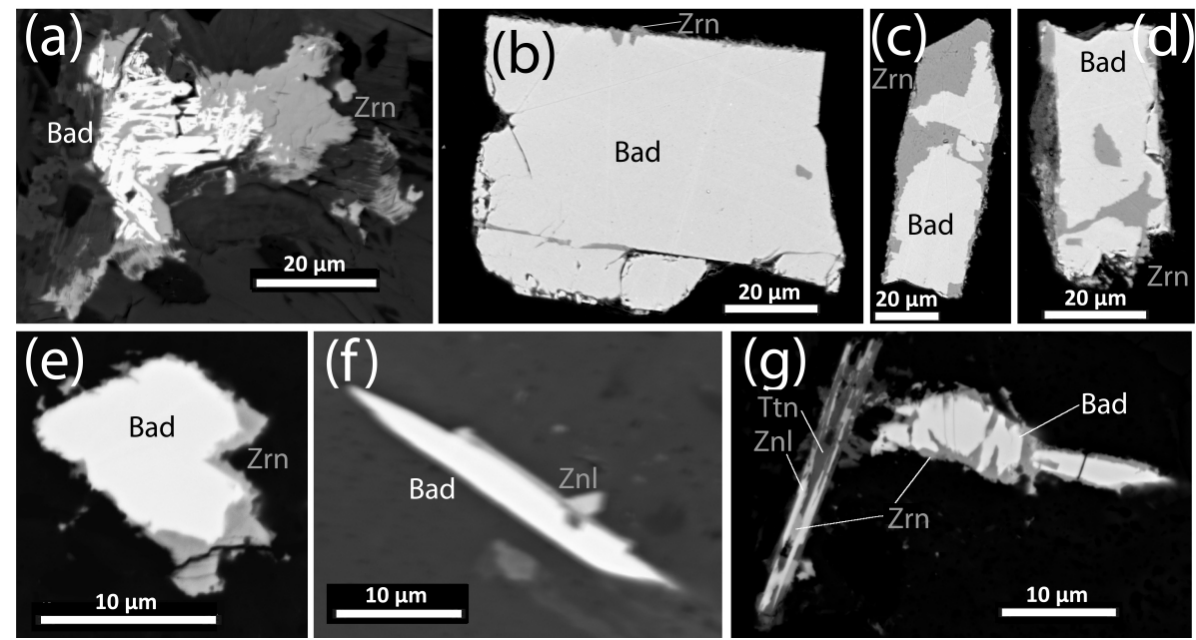

Figure 3. Backscatter electron (BSE) images of accessory minerals in the SEIC. (a) Baddeleyite (Bad) clusters surrounded by zircon (Zrn) from sample FP1F. (b-d) Mineral separates of baddeleyite from sample FP6D, showing variable proportions of zircon domains. (e) Baddeleyite with thin zircon rims from sample FP7G. (f) Baddeleyite-zirconolite (Znl) intergrowth from sample FP7G. (g) Baddeleyite and zirconolite surrounded by zircon and titanite (Ttn).

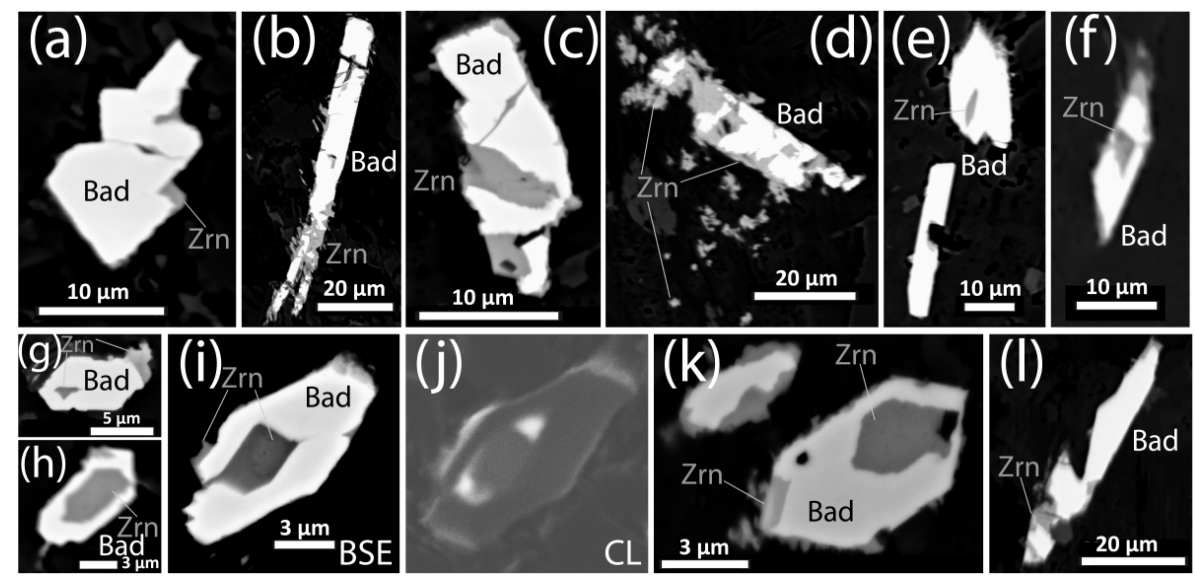

Figure 4. BSE and cathodoluminescence (CL; j) images of baddeleyite-zircon intergrowths in SEIC sample FP12A. (a-d) Baddeleyite of different habits, intergrown with variable proportions of zircon. (e-l) Baddeleyite with zircon inclusions and notches.

euhedral $(\leq 20 \mu \mathrm{m})$ or anhedral $(\leq 50 \mu \mathrm{m})$ crystals. Only one sample (FP7G) contains zirconolite $\mathrm{CaZrTi}_{2} \mathrm{O}_{7}$ (all mineral formulae given as stochiometric end-members from Anthony et al., 2001) and rare pyrochlore $(\mathrm{Ca}, \mathrm{Na})_{2} \mathrm{Nb}_{2} \mathrm{O}_{6}(\mathrm{OH}, \mathrm{F})$ in addition to baddeleyite and zircon. Zirconolite occurs mainly in the vicinity of baddeleyite crystals of similar size and form (Fig. 3f). It sometimes has an altered appearance and/or significant $\mathrm{Si}$ contents. In rare cases it is partly replaced by titanite + zircon (Fig. 3g).

\subsection{Cape St. Mary's sills (CSMS)}

CSMS gabbros are less altered than those of the SEIC. Sample S2B represents a typical CSMS gabbro regarding major phase mineralogy (clinopyroxene, albite, titanomagnetite, partly chloritized biotite, chlorite pseudomorphs) and has ilmenite, $\mathrm{Cr}$ spinel, ilvaite $\mathrm{CaFe}_{2}^{2+} \mathrm{Fe}^{3+} \mathrm{Si}_{2} \mathrm{O}_{7} \mathrm{O}(\mathrm{OH})$ and sulfides as minor to accessory phases. Baddeleyite is the predominant Zr-bearing mineral, coexisting with zirconolite and minor zircon. Habits of baddeleyite vary from euhedral to anhedral and are needle-shaped $(2 \mu \mathrm{m} \times 300 \mu \mathrm{m})$ to prismatic $(10 \mu \mathrm{m} \times 20 \mu \mathrm{m})$. Zircon rims are rare.

In contrast to the gabbros, granophyres are strongly leucocratic ( $>70 \mathrm{vol} \%$ albite). Albite crystals are typically $1 \mathrm{~cm} \times 0.5 \mathrm{~cm}$ large in the interior of granophyre pockets, whereas the outermost ca. $5 \mathrm{~cm}$ of the pockets are somewhat less leucocratic with smaller albite crystals. Nonetheless, a strong contrast of grain size and mineralogy characterizes the sharp contact between gabbros and granophyre pockets. Granophyre samples S2C (center of a pocket) and 

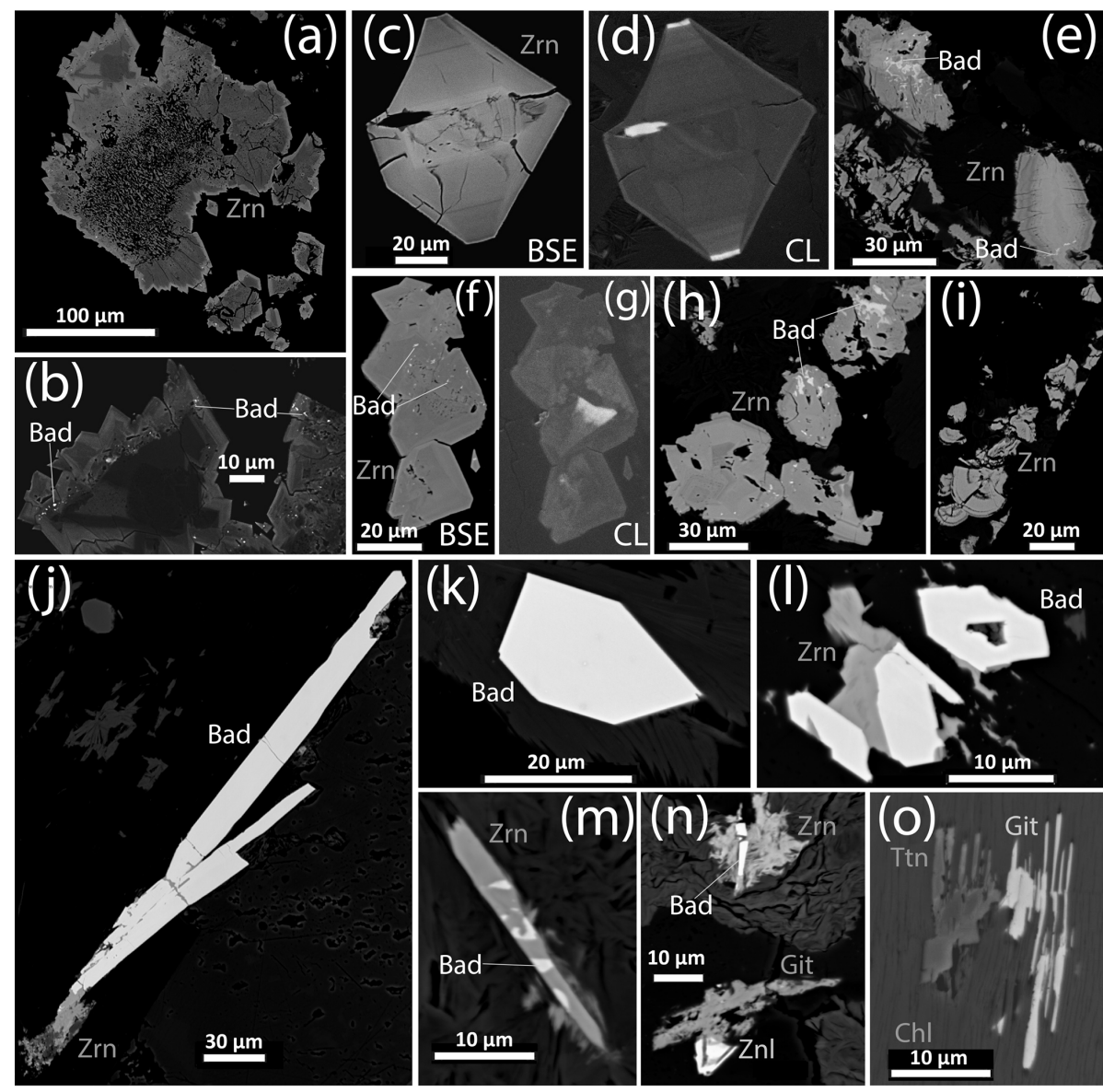

Figure 5. BSE and CL images of accessory minerals in CSMS. (a-i) Different habits of zircon in sample S2C, most of them with baddeleyite inclusions. (j-l) Euhedral baddeleyite with and without zircon intergrowth. (m) Relict baddeleyite within zircon pseudomorph, with a featherlike zircon corona. (n) Baddeleyite and zirconolite, intergrown with zircon and gittinsite. (o) Gittinsite-titanite intergrowth within chlorite.

S2E (transition of a pocket center to the gabbro contact) are largely identical in major phases (albite, clinopyroxene, ilmenite, chlorite, biotite \pm Ti-rich hornblende). However, the accessory mineral assemblages are highly different. In S2C, zircon is the only Zr-bearing phase with contact to groundmass minerals. Crystals are up to $200 \mu \mathrm{m}$ large, isometrical and growth zoned. Shapes vary from euhedral sector zoned with radial cracks in the outer zones (Fig. 5c) over grain clusters (Fig. 5f) to fan-shaped forms (Fig. 5i). BSE and CL intensities are usually inversely correlated (Fig. 5f, g). Some crystals have partly microporous textures and contain anhedral baddeleyite inclusions (mostly $<2 \mu \mathrm{m}$, max. $4 \mu \mathrm{m} \times 10 \mu \mathrm{m}$ in size), usually in the outer zones. Sometimes the inclusions seem to retrace cracks or crystallographical orientations (Fig. 5e). In S2E, the pocket interior has large (up to $200 \mu \mathrm{m}$ ) zircon crystals but without baddeleyite inclusions, whereas baddeleyite sometimes forms isolated crystals in the groundmass. Towards the gabbro contact, baddeleyite becomes more and more predominant until the presence of zircon is mostly confined to baddeleyite replacement textures. Near the gabbro contact, baddeleyite occurs either as euhedral lath-shaped crystals with dimensions up to $20 \mu \mathrm{m} \times 300 \mu \mathrm{m}$ (Fig. 5j) or as short prismatic crystals up to $30 \mu \mathrm{m}$ in diameter (Fig. 5k). Baddeleyite within albite usually lacks zircon intergrowths. Contrastingly, most baddeleyite within chlorite pseudomorphs is pseudomorphically replaced by zircon, sometimes containing baddeleyite relicts, and surrounded by a feather-like zircon corona (Fig. $5 \mathrm{~m}$ ). Near the gabbro contact, zircon with amoeboidal grain boundaries occurs, as well as zirconolite and gittinsite $\mathrm{CaZrSi}_{2} \mathrm{O}_{7}$. Gittinsite has not been reported from similar rock types before. Textures include gittinsite-zirconolite intergrowths (Fig. 5n) and gittinsite-titanite intergrowths branching along the fissure plains of surrounding chlorite (Fig. 5o). 
Table 2. Summary of U-Pb SIMS results (see Tables S1-S6 for the detailed data).

\begin{tabular}{lrrrrrrrr}
\hline & $n^{\mathrm{b}}$ & $\begin{array}{r}{ }^{206} \mathrm{~Pb} /{ }^{238} \mathrm{U} \\
\text { date (Ma) }\end{array}$ & $\pm 2 \sigma$ & $\pm 2 \sigma^{\mathrm{a}}$ & $\mathrm{MSWD}$ & $\begin{array}{r}{ }^{207} \mathrm{~Pb} /{ }^{206} \mathrm{~Pb} \\
\text { date }(\mathrm{Ma})\end{array}$ & $\pm 2 \sigma$ & $\mathrm{MSWD}$ \\
\hline FP6D gm baddeleyite1 & $24(20)$ & 516.2 & 14.9 & 21.2 & 2.03 & 500.8 & 18.0 & 0.54 \\
FP6D gm baddeleyite2 & $30(30)$ & 531.9 & 14.1 & & 0.38 & 502.5 & 8.6 & 0.83 \\
FP6D gm baddeleyite3 & $28(27)$ & 563.4 & 13.6 & 15.2 & 1.25 & 484.1 & 13.5 & 0.65 \\
Sessions 1-3 & & 539.1 & 8.3 & 10.1 & 1.48 & 497.0 & 6.8 & 0.75 \\
FP6D gm zircon & $10(4)$ & $142-517$ & - & & - & $247-678$ & - & - \\
FP7G ins baddeleyite1 & $10(4)$ & 544.7 & 46.8 & & 0.39 & 511.3 & 81.8 & 0.43 \\
FP7G ins baddeleyite2 & $16(7)$ & 526.0 & 24.2 & & 0.43 & 444.1 & 163.4 & 0.20 \\
Sessions 1-2 & & 529.9 & 21.4 & & 0.42 & 497.8 & 73.2 & 0.30 \\
FP7G ins zircon & $1(1)$ & 263.8 & 11.5 & & - & 732 & 432 & - \\
FP12A ins baddeleyite1 & $16(8)$ & 509.6 & 11.8 & 17.5 & 2.19 & 479 & 111 & 0.39 \\
FP12A ins baddeleyite2 & $6(4)$ & 527.5 & 63.0 & & 0.91 & 725 & 160 & 0.54 \\
FP12A ins baddeleyite3 & $6(4)$ & 468.2 & 53.6 & & 0.95 & 520 & 264 & 0.05 \\
FP12A ins baddeleyite4 & $5(2)$ & 505.7 & 62.6 & 83.0 & 1.76 & 418 & 346 & 1.30 \\
Sessions 1-4 & & 508.2 & 11.2 & 13.7 & 1.49 & 546.6 & 83.6 & 0.76 \\
FP12A ins zirconc & $6(3)$ & $311-408$ & - & & - & $325-417$ & - & - \\
S2C ins zircon & $23(13)$ & 426.8 & 26.4 & & 0.46 & 373.6 & 48.4 & 0.88 \\
S2E ins baddeleyite & $24(21)$ & 446.6 & 12.8 & 15.4 & 1.44 & 436.5 & 21.2 & 0.82 \\
S2E gm baddeleyite & $42(39)$ & 491.0 & 19.8 & & 0.45 & 425.5 & 8.7 & 1.00 \\
S2E ins zircon & $5(1)$ & 402.0 & 51.2 & & - & 846 & 340 & - \\
S2E gm zircon & $8(7)$ & $411-443$ & - & & - & $282-443$ & - & - \\
SL18 ins baddeleyite & $41(34)$ & 201.2 & 3.2 & 7.2 & 5.05 & 180.2 & 66.0 & 0.21 \\
SL18 gm baddeleyite & $61(61)$ & 202.5 & 2.2 & & 0.78 & 184.3 & 12.5 & 0.79 \\
\hline
\end{tabular}

ins represents in situ, gm represents grain mount. ${ }^{\mathrm{a}} 2 \sigma$ uncertainty multiplied with the square root of the MSWD (mean square weighted deviation) for samples with MSWD $>1$; ${ }^{b}$ number in parentheses is without analyses that have high common $\mathrm{Pb}\left(<90 \%\right.$ radiogenic $\left.{ }^{206} \mathrm{~Pb}\right)$ or contain contributions from other U-bearing minerals. These analyses are excluded from weighted mean calculations. For zircon, a range of dates is given instead of weighted means, as the crystals may belong to several generations and/or have undergone strongly variable $\mathrm{Pb}$ loss. ${ }^{\mathrm{c}}$ not including zircon inclusions in baddeleyite. Analyses were acquired during sessions FP12A baddeleyite1-3.

\section{$5 \mathrm{U}-\mathrm{Pb}$ results}

\subsection{SIMS data}

The SEIC SIMS data are presented in Fig. 6 (summary in Table 2; detailed data in Tables S1-S6 in the Supplement). In situ baddeleyite analyses of sample FP7G yielded weighted mean dates of $529.9 \pm 21.4 \mathrm{Ma}$ $\left({ }^{206} \mathrm{~Pb} /{ }^{238} \mathrm{U}\right)$ and $497.8 \pm 73.2 \mathrm{Ma}\left({ }^{207} \mathrm{~Pb} /{ }^{206} \mathrm{~Pb}\right)$. For FP12A baddeleyite, the weighted mean dates are 508.2 $\pm 11.2 \mathrm{Ma}$ $\left({ }^{206} \mathrm{~Pb} /{ }^{238} \mathrm{U}\right)$ and $546.6 \pm 83.6 \mathrm{Ma}\left({ }^{207} \mathrm{~Pb} /{ }^{206} \mathrm{~Pb}\right)$. Many baddeleyite analyses show surprisingly high contents of common $\mathrm{Pb}$; those with $<90 \%$ radiogenic ${ }^{206} \mathrm{~Pb}$ were generally excluded from weighted mean calculations. During grain mount sessions, FC-4b baddeleyite was analyzed as a secondary reference in addition to Phalaborwa baddeleyite. Weighted mean ${ }^{206} \mathrm{~Pb} /{ }^{238} \mathrm{U}$ dates of $\mathrm{FC}-4 \mathrm{~b}$ calculated with Phalaborwa reference are $1118 \pm 39 \mathrm{Ma}$ $(\mathrm{MSWD}=0.63 ; n=28), 1101 \pm 44 \mathrm{Ma}(\mathrm{MSWD}=0.41 ; n=$ $29), 1124 \pm 56 \mathrm{Ma}$ (MSWD $=0.91 ; n=9$ ) and $1117 \pm 23 \mathrm{Ma}$ $(\mathrm{MSWD}=2.42 ; n=18$; session with sample S2E). Therefore, in all grain mount sessions, the ${ }^{206} \mathrm{~Pb} /{ }^{238} \mathrm{U}$ ID-TIMS reference age of FC-4b $(1096.84 \pm 0.45 \mathrm{Ma}$; Schmitt et al., 2010) was reproduced within error limits. Likewise, the
${ }^{207} \mathrm{~Pb} /{ }^{206} \mathrm{~Pb}$ dates we obtained for Phalaborwa (2058.8 \pm $0.7 \mathrm{Ma}, \mathrm{MSWD}=6.3, n=254)$ and FC-4b baddeleyite $(1096.0 \pm 2.9 \mathrm{Ma}, \mathrm{MSWD}=1.1, n=84)$ are in good agreement with the ID-TIMS ${ }^{207} \mathrm{~Pb} /{ }^{206} \mathrm{~Pb}$ data $(2059.6 \pm 0.35 \mathrm{Ma}$; Heaman, 2009; and 1099.6 \pm 1.5 Ma; Schmitt et al., 2010). Because of the consistency of Phalaborwa and FC-4b results, analyses from both reference materials were combined for obtaining the $\mathrm{U} / \mathrm{Pb}$ relative sensitivity factor. Despite the good agreement of ${ }^{206} \mathrm{~Pb} /{ }^{238} \mathrm{U}$ dates of the reference baddeleyite, ${ }^{206} \mathrm{~Pb} /{ }^{238} \mathrm{U}$ dates of baddeleyite from sample FP6D obtained during the same sessions were less reproducible $(516.2 \pm 21.2,531.9 \pm 14.1$ and $563.4 \pm 15.2 \mathrm{Ma})$, with reverse discordance in sessions two and three (Fig. 6b, c). However, ${ }^{207} \mathrm{~Pb} /{ }^{206} \mathrm{~Pb}$ dates of these sessions are consistent $(500.8 \pm 18.0,502.5 \pm 8.6$ and $484.1 \pm 13.5 \mathrm{Ma})$, yielding a total weighted mean ${ }^{207} \mathrm{~Pb} /{ }^{206} \mathrm{~Pb}$ date of $497.0 \pm 6.8 \mathrm{Ma}$ $(\mathrm{MSWD}=0.75 ; n=77)$. Common- $\mathrm{Pb}$ contents tend to be lower than in FP7G and FP12A but are often still significant. Zircon rims on baddeleyite and baddeleyite-free zircon from all SEIC samples yielded a wide range of ${ }^{206} \mathrm{~Pb} /{ }^{238} \mathrm{U}$ dates from 142 to $517 \mathrm{Ma}$ (Fig. 6d, f). At least for sample FP6D, ${ }^{206} \mathrm{~Pb} /{ }^{238} \mathrm{U}$ dates become younger with increasing $\mathrm{U}$ contents. Zircon analyses from SEIC samples have mostly high common- $\mathrm{Pb}$ contents $\left(<90 \%\right.$ radiogenic $\left.{ }^{206} \mathrm{~Pb}\right)$. Zir- 

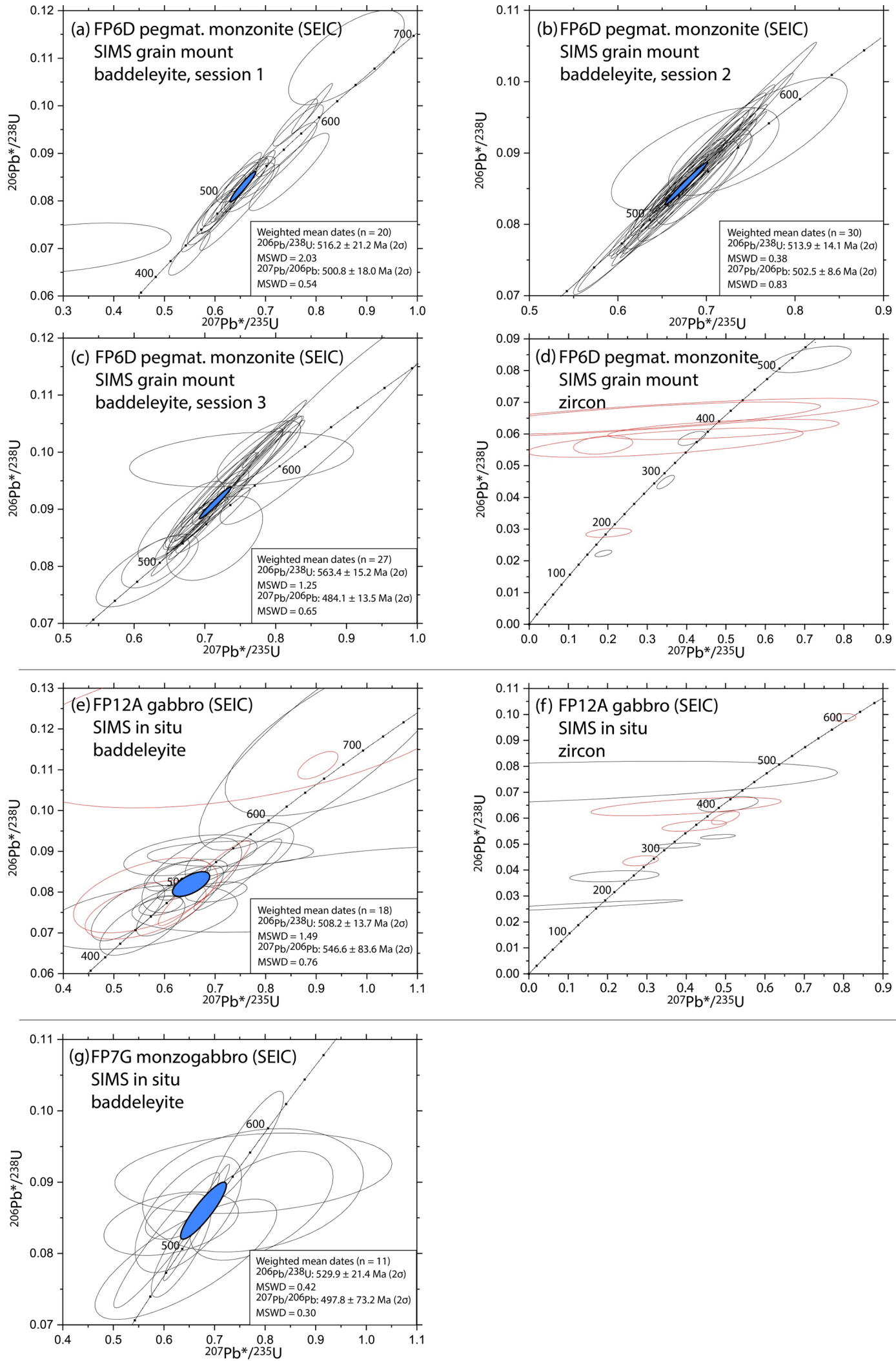

Figure 6. SIMS U-Pb baddeleyite and zircon results for SEIC samples. Ellipses in red represent analyses of baddeleyite with zircon inclusions (e) or zircon analyses with $<90 \%$ radiogenic ${ }^{206} \mathrm{~Pb}(\mathbf{d}, \mathbf{f})$. Error ellipses of individual analyses are $1 \sigma$, whereas the weighted mean ellipse (blue) is enlarged to $2 \sigma$. 

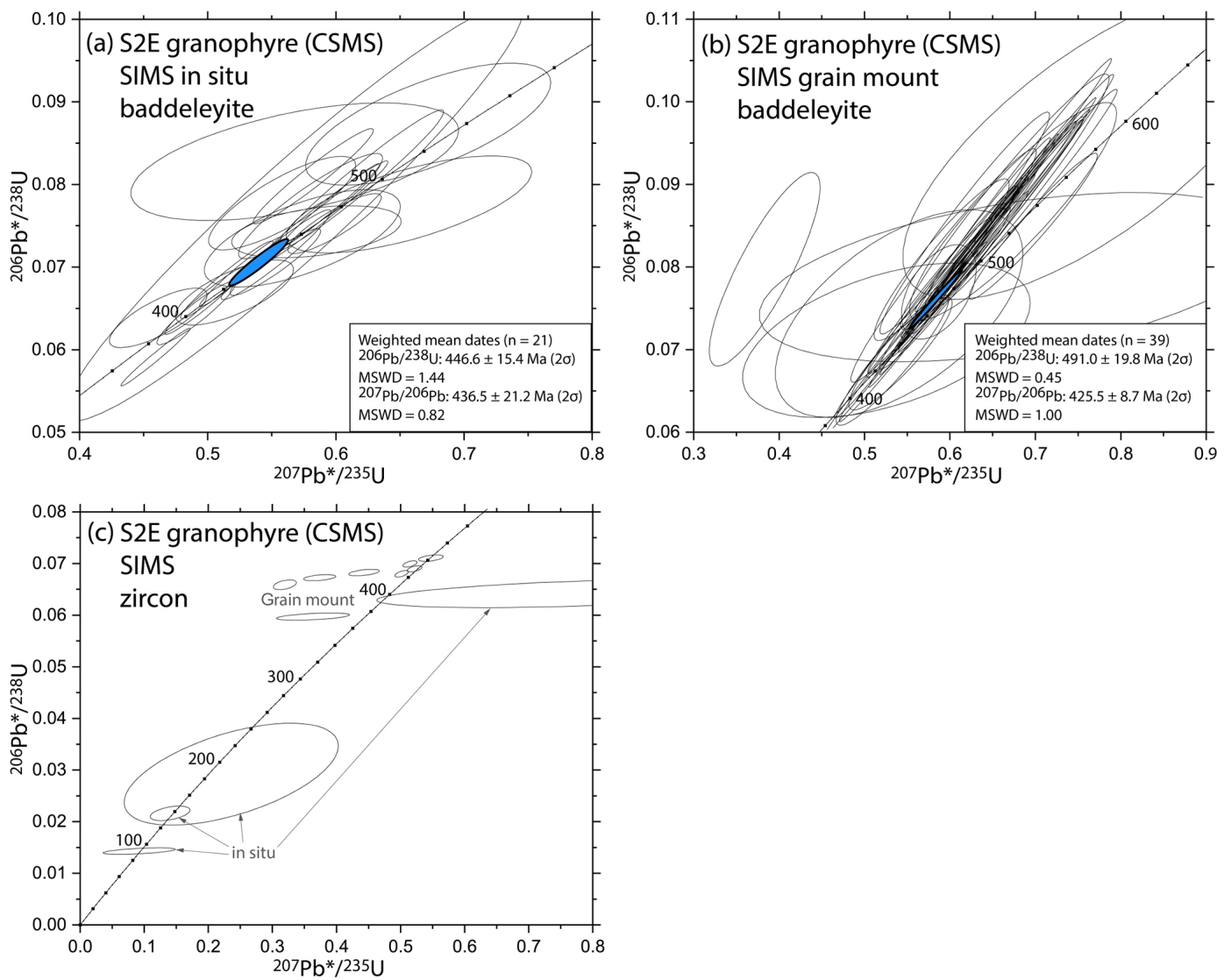

Figure 7. SIMS U-Pb baddeleyite (a, b) and zircon (c) results for CSMS samples. Error ellipses of individual analyses (only those used for weighted mean date calculations are shown) are $1 \sigma$, whereas the weighted mean ellipse (blue) is enlarged to $2 \sigma$.

con inclusions in baddeleyite (FP12A) yielded ${ }^{206} \mathrm{~Pb} /{ }^{238} \mathrm{U}$ date ranges of 470-733 Ma and 297-607 Ma for baddeleyiteand zircon-based RSC, respectively.

For CSMS, baddeleyite of sample S2E (Fig. 7; Tables 2 and S5) yielded weighted mean dates of $446.6 \pm 15.4 \mathrm{Ma}$ $\left({ }^{206} \mathrm{~Pb} /{ }^{238} \mathrm{U} ; \mathrm{MSWD}=1.44 ; n=21\right)$ and $436.5 \pm 21.2 \mathrm{Ma}$ $\left({ }^{207} \mathrm{~Pb} /{ }^{206} \mathrm{~Pb} ; \mathrm{MSWD}=0.82\right)$ from the in situ session. In contrast, the grain mount session of the same sample yielded $491.0 \pm 19.8 \mathrm{Ma}\left({ }^{206} \mathrm{~Pb} /{ }^{238} \mathrm{U} ; \mathrm{MSWD}=0.45 ; n=39\right)$ and $425.5 \pm 8.7 \mathrm{Ma}\left({ }^{207} \mathrm{~Pb} /{ }^{206} \mathrm{~Pb} ; \mathrm{MSWD}=1.00\right)$, showing reverse discordance (Fig. 7b). ${ }^{206} \mathrm{~Pb} /{ }^{238} \mathrm{U}$ zircon dates from grain mounts are in the range of 411-443 Ma with moderate or low common- $\mathrm{Pb}$ contents, but in situ dates of anhedral zircon in chlorite pseudomorphs are much younger, combined with high $\mathrm{U}$ and common-Pb contents. Zircon dates from S2C (Fig. S9; Table S4) are often younger than S2E baddeleyite, but most analyses show high common $\mathrm{Pb}$.

For SL18, weighted mean dates are $202.5 \pm 2.2 \mathrm{Ma}$ $\left({ }^{206} \mathrm{~Pb} /{ }^{238} \mathrm{U}\right)$ and $182.7 \pm 12.5 \mathrm{Ma}\left({ }^{207} \mathrm{~Pb} /{ }^{206} \mathrm{~Pb}\right)$ for the grain mount session and $201.3 \pm 7.2 \mathrm{Ma}\left({ }^{206} \mathrm{~Pb} /{ }^{238} \mathrm{U}\right)$ and $177.4 \pm 65.4 \mathrm{Ma}\left({ }^{207} \mathrm{~Pb} /{ }^{206} \mathrm{~Pb}\right.$ ) for the in situ session (Fig. 9; Tables 2, S6). The ${ }^{206} \mathrm{~Pb} /{ }^{238} \mathrm{U}$ dates from these sessions are in good agreement with the CAMP age of $\sim 201.5$ Ma based on worldwide samples using zircon (Blackburn et al., 2013; Davies et al., 2017).

\subsection{ID-TIMS data}

ID-TIMS analyses of baddeleyite from SEIC (sample FP6D) and CSMS (sample S2E) yielded normally discordant data that form linear arrays (Fig. 8; Table 3). The upper intercept dates are $498.7 \pm 4.5 \mathrm{Ma}(\mathrm{FP} 6 \mathrm{D})$ and $437.0 \pm 7.9 \mathrm{Ma}$ (S2E). The weighted mean ${ }^{207} \mathrm{~Pb} /{ }^{206} \mathrm{~Pb}$ date of S2E is $444.1 \pm$ $4.4 \mathrm{Ma}$ ( $95 \%$ confidence; $\mathrm{MSWD}=0.82$ ), within error of the upper intercept date. In contrast, ${ }^{207} \mathrm{~Pb} /{ }^{206} \mathrm{~Pb}$ dates of FP6D show scatter beyond uncertainty (Fig. 8c) with a weighted mean that is statistically meaningless $(\mathrm{MSWD}=5.5)$. For both samples, there is a direct correlation between the ${ }^{207} \mathrm{~Pb} /{ }^{206} \mathrm{~Pb}$ dates and the percentage of discordance, leading to negative lower intercepts for linear regressions on concordia plots (Fig. 8). Like the corresponding SIMS analyses, baddeleyite analyses from FP6D and S2E contained significant common $\mathrm{Pb}$ (up to $6 \mathrm{pg}$ ). However, we tested different common- $\mathrm{Pb}$ isotopic compositions and blank/non-blank proportions and no geologically realistic choice produces consistent ${ }^{207} \mathrm{~Pb} /{ }^{206} \mathrm{~Pb}$ dates for sample FP6D (see Sect. S5 

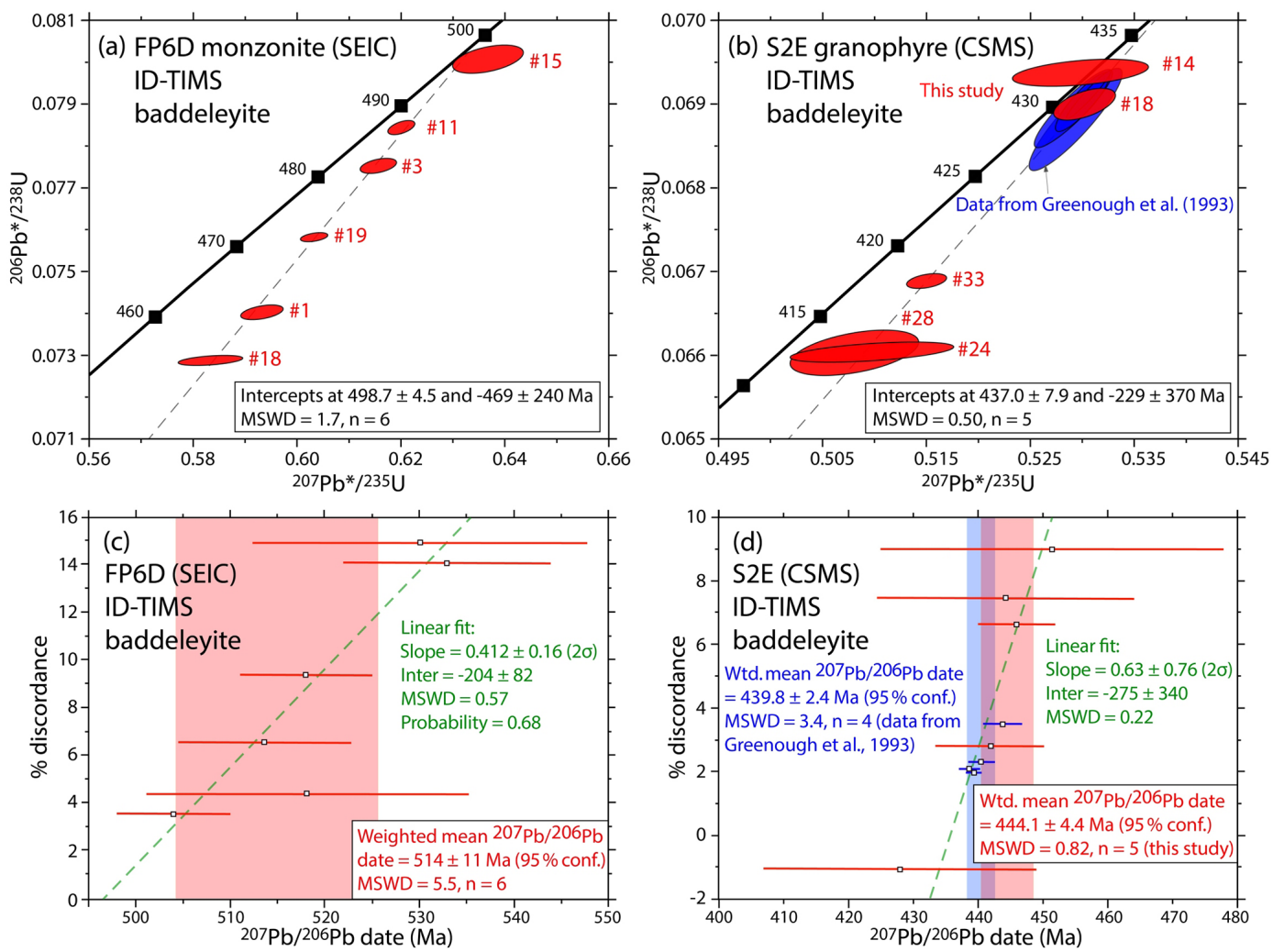

Figure 8. ID-TIMS U-Pb results for samples FP6D and S2E. ${ }^{207} \mathrm{~Pb} /{ }^{206} \mathrm{~Pb}$ dates are less scattered than ${ }^{206} \mathrm{~Pb} /{ }^{238} \mathrm{U}$ dates but show a linear correlation with the percentage of discordance. All error bars and ellipses represent $2 \sigma$ uncertainties.

for details), thus the increase in ${ }^{207} \mathrm{~Pb} /{ }^{206} \mathrm{~Pb}$ dates with increasing discordance must be attributed to the radiogenic $\mathrm{Pb}$ in FP6D baddeleyite. Furthermore, the negative lower intercepts are controlled by the most discordant analyses, as a regression of the four most discordant analyses from FP6D, the ones with the most total $\mathrm{Pb}$ loss, leads to a lower intercept of $-462 \pm 430 \mathrm{Ma}$ (Sect. S5), negative outside of error and similar to the regression using all six analyses.

Additional ID-TIMS data for very small baddeleyite crystals of sample SL18 (Fig. 9c; Table 3) yielded ${ }^{206} \mathrm{~Pb} /{ }^{238} \mathrm{U}$ dates that are younger than those of the larger crystals of SL18 published in Callegaro et al. (2017). All analyses overlap with Concordia within uncertainty and have low common- $\mathrm{Pb}$ contents $(\sim 0.5 \mathrm{pg})$ which are attributed to laboratory blank rather than initial common $\mathrm{Pb}$ or common $\mathrm{Pb}$ that has been added during a secondary alteration process.

\section{Discussion}

\subsection{Occurrence, textures and interrelations of accessory minerals}

Zirconium-bearing accessory minerals in mafic magmas form during late stages of crystallization in more differentiated interstitial melt (Heaman and LeCheminant, 1993;
Schaltegger and Davies, 2017). In our study, abundance and crystal size of accessory minerals lack a strong correlation with whole-rock Zr content (Sect. S7), but the more coarsegrained samples tend to contain larger baddeleyite and zircon crystals. Regardless of crystal sizes, baddeleyite and zircon in SEIC and CSMS rocks form various types of intergrowths. Baddeleyite in mafic rocks is typically of igneous origin, but metamorphic processes can cause it to react to polycrystalline zircon (Heaman and LeCheminant, 1993). Metamorphic zircon is therefore expected to be the most common type of zircon intergrown with baddeleyite in SEIC and CSMS rocks, which all have experienced low-grade metamorphism. Although probably less common, magmatic zircon overgrowths on pre-existing baddeleyite can also form during late-stage igneous crystallization due to an increased $\mathrm{SiO}_{2}$ activity in the melt (e.g., Renna et al., 2011). Such igneous zircon overgrowths on baddeleyite have rather euhedral crystal faces and straight interfaces with baddeleyite (Renna et al., 2011). By contrast, metamorphic zircon shares more irregular crystal interfaces with baddeleyite and has an anhedral exterior, described as "raspberry texture" (Heaman and LeCheminant, 1993) or "frosty appearance" (Söderlund et al., 2013). For SEIC and CSMS, the typical textural features of igneous zircon overgrowth on baddeleyite are rarely displayed (Fig. 5l), whereas features of metamorphic 


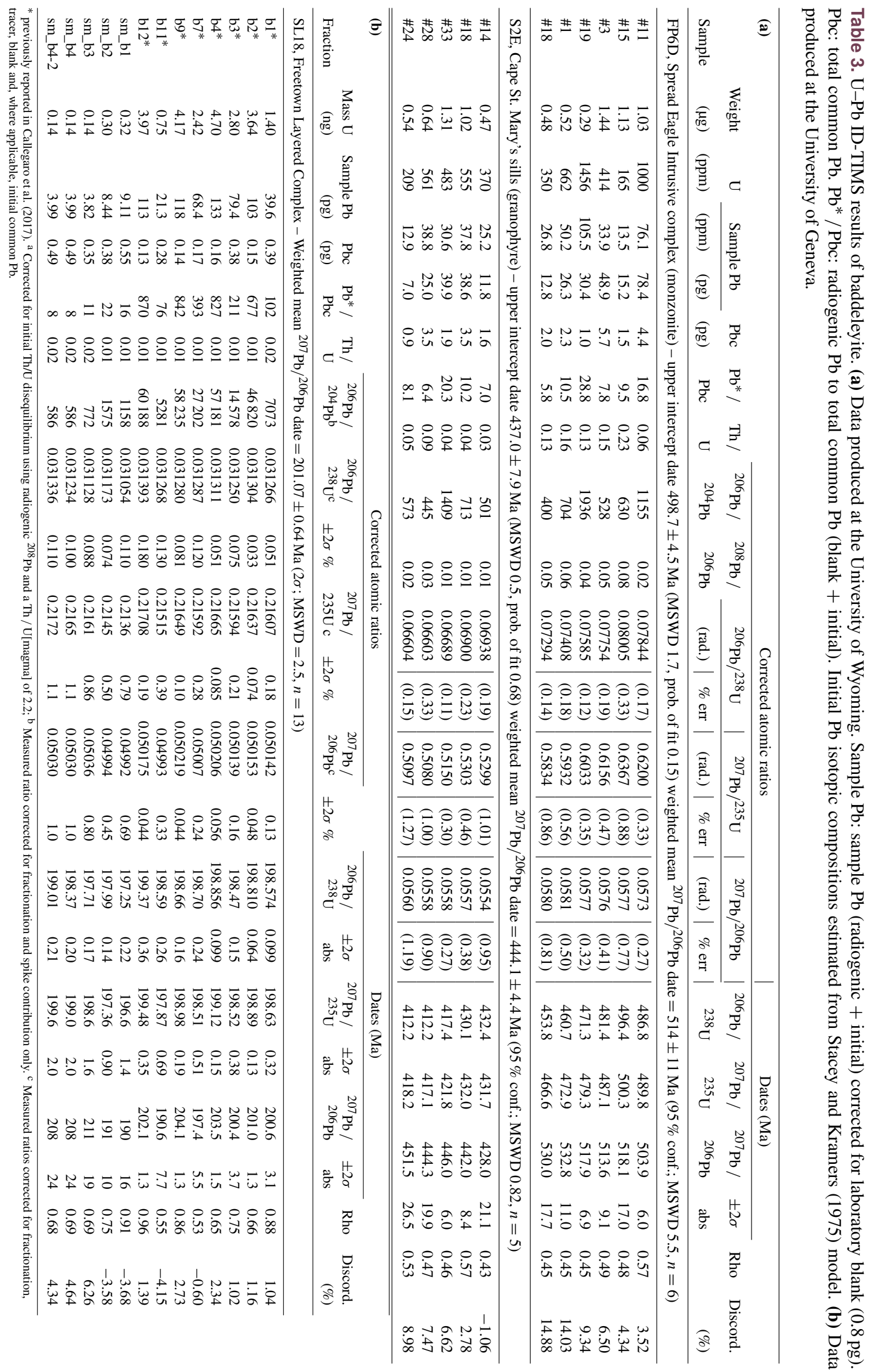



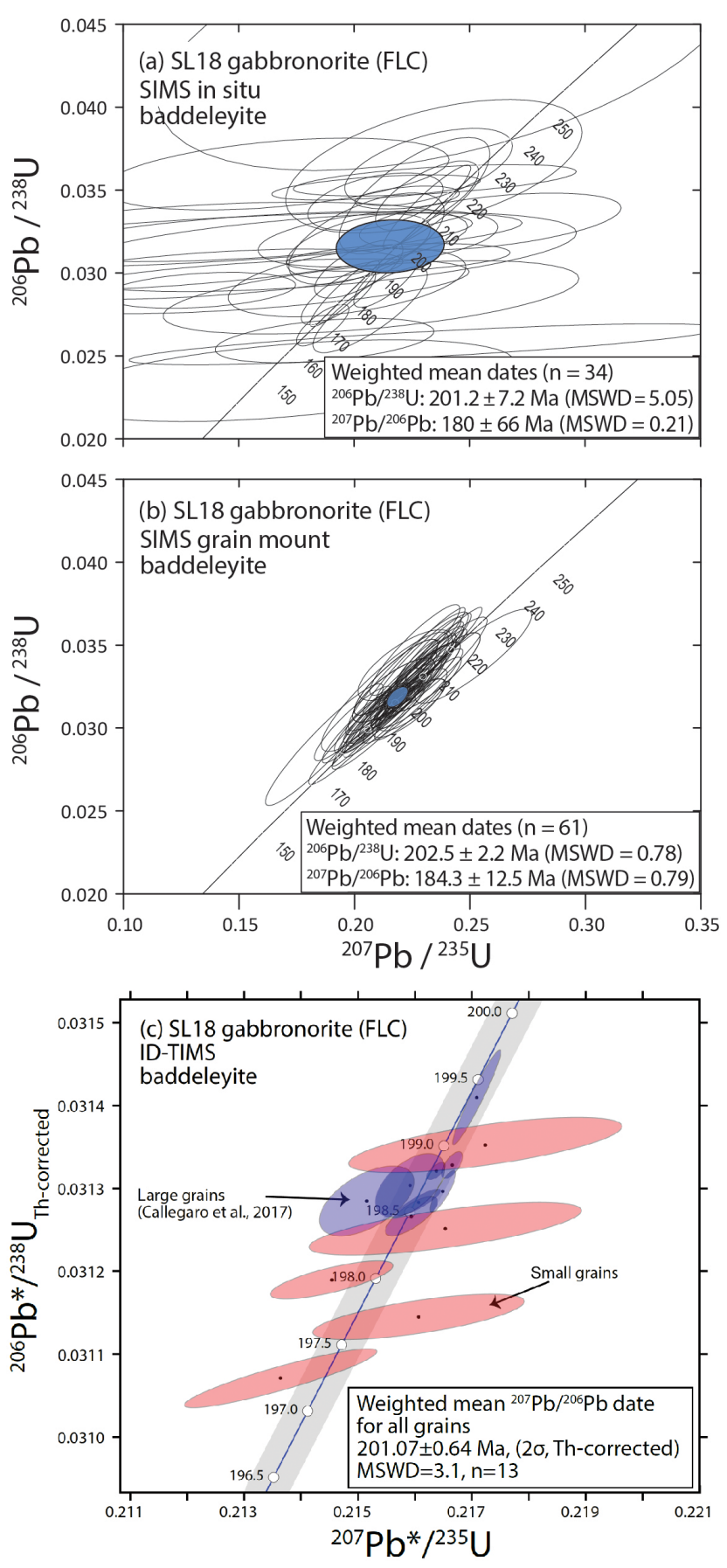

Figure 9. U-Pb baddeleyite data of sample SL18. For the SIMS analyses $(\mathbf{a}, \mathbf{b})$, error ellipses of individual analyses are $1 \sigma$, whereas the weighted mean ellipse (blue) is enlarged to $2 \sigma$. For the ID-TIMS data (c) of large crystals (blue; Data from Callegaro et al., 2017) and small crystals (red; this study), all ellipses represent $2 \sigma$ uncertainties.

replacement zircon are frequently observed. Zircon seems to pseudomorphically replace baddeleyite, accompanied by feather-like zircon coronas (e.g., Figs. 4d, 5l), probably due to volume enlargement by the addition of silica during meta- morphism. The presence of such coronas can therefore help to distinguish zircon with a baddeleyite precursor from primary zircon in altered igneous rocks.

The extent of baddeleyite replacement by zircon in this study often depends on the host minerals. Baddeleyite surrounded by chlorite shows replacement by zircon more commonly than baddeleyite in albite or epidote group minerals, and baddeleyite inclusions in $\mathrm{K}$-feldspar mostly lack zircon. We attribute this to local variations in the $\mathrm{SiO}_{2}$ activity during metamorphism: the chloritization of pyroxenes liberates large amounts of $\mathrm{Si}$, whereas alteration of alkali feldspars has a neutral Si balance. Si release sometimes also causes replacement of zirconolite by titanite + zircon (Fig. 3g) or titanite + gittinsite (Fig. 5o).

Alteration by fluids with high $\mathrm{SiO}_{2}$ activity causes baddeleyite replacement by zircon, but fluids poor in $\mathrm{Si}$ and rich in $\mathrm{Ca}$ can induce the opposite effect even in siliceous rocks (Lewerentz et al., 2019). In sample S2C, multiple micrometer-sized baddeleyite inclusions are hosted in the outer zones of zircon, which shows porous domains (Fig. 5a), cracks (Fig. 5c), and high contents of common $\mathrm{Pb}$, which are typical alteration features (e.g., Corfu et al., 2003; Rayner et al., 2005; Aranovich et al., 2017). Whereas other fluidmediated processes may also be capable of forming secondary baddeleyite inclusions in altered zircon (Lewerentz et al., 2019), the former presence of fluids with high $\mathrm{Ca} / \mathrm{Si}$ ratio in S2C is likely due to widespread albitization of plagioclase. Previously reported occurrences of secondary baddeleyite inclusions in zircon are from rocks that experienced high-temperature (mostly amphibolite facies) alteration (Barth et al., 2002; Aranovich et al., 2013, 2017; Lewerentz et al., 2019), and experiments reproducing this texture were conducted at 600 and $900{ }^{\circ} \mathrm{C}$ (Lewerentz et al., 2019). However, Cape St. Mary's sills have experienced only subgreenschist facies (Greenough and Papezik, 1986b) or, at most, lower greenschist facies conditions. Hence, we present the first evidence that secondary baddeleyite inclusions in zircon can also form at low temperatures, and low-temperature reactions of zircon to baddeleyite and vice versa can occur within the same dike.

A peculiar texture in sample FP12A is baddeleyite with zircon inclusions (Fig. 4e-k). BSE and CL images provide only two-dimensional petrographic information, so it can be argued whether these are only apparent inclusions as part of metamorphic zircon rims that locally penetrate the crystal. However, most of these baddeleyite crystals lack any visible zircon overgrowth, and the baddeleyite mantle is coherent even when as thin as $1 \mu \mathrm{m}$. Furthermore, we observed this texture repeatedly in sample FP12A but not in other samples. Thus this texture most likely represents actual zircon inclusions of xenocrystic origin. An attempt to test this hypothesis with SIMS dating of these zircon inclusions yielded an older ${ }^{206} \mathrm{~Pb} /{ }^{238} \mathrm{U}$ date only for one crystal (Fig. 4e; Table S3, analysis 1_3) but the primary beam overlapped both the baddeleyite and zircon. Furthermore, difficulties with the 
RSC (see Sect. 6.2.1) and/or Pb loss from possibly metamict zircon may have biased the results. Lastly, the xenocrysts may be derived from an assimilated Cambrian or Ediacaran sedimentary country rocks, whose detrital zircon is often not much older than ca. $500 \mathrm{Ma}$ (Pollock et al., 2009), which is roughly the age of FP12A.

In a hot, low $\mathrm{SiO}_{2}$ activity magma such as the primary magma of FP12A, xenocrystic zircon is undersaturated and dissolves (see Boehnke et al., 2013). Slow Zr diffusion in the melt limits the zircon dissolution rate, so that the melt adjacent to the zircon will develop an exponentially decreasing $\mathrm{Zr}$ concentration gradient (e.g., Harrison and Watson, 1983). Hence, partially dissolved xenocrystic zircon will be surrounded by a halo of elevated $\mathrm{Zr}$ concentration in the zirconundersaturated magma. Such a halo of elevated $\mathrm{Zr}$ concentrations is a preferential location for baddeleyite nucleation, even if the bulk of the magma remains undersaturated with regard to baddeleyite. Once a nucleus is formed, baddeleyite will grow preferentially where $\mathrm{Zr}$ concentration is highest (at the dissolution interface). If a coherent baddeleyite mantle is formed, the zircon xenocryst becomes shielded from further dissolution.

Although such xenocrystic inclusions can be overlooked easily, the lack of previous reports suggests that this is a rare texture. This may be a consequence of numerous factors:

1. A melt with low $\mathrm{SiO}_{2}$ activity is needed, being zirconundersaturated, but close to baddeleyite saturation.

2. The country rock must have zircon but should not be too siliceous, because otherwise zircon would be stabilized and baddeleyite destabilized. If the country rock is only weakly consolidated, zircon liberation is facilitated.

3. High temperatures and low crystal fraction of the magma are necessary to assimilate country rock effectively. However, this also favors rapid dissolution of zircon or xenocrysts or their entrapment in major phases before baddeleyite saturation is achieved.

4. In specific cases, baddeleyite may fail to enclose zircon before the latter dissolves completely. This may leave a notch on the baddeleyite crystal, such as in Fig. 4e and $\mathrm{k}$.

Our detailed micropetrography revealed that baddeleyite and zircon can be intergrown in various ways, especially for samples with complex metamorphic histories. Including our newly proposed xenocrystic zircon inclusions in baddeleyite, at least seven different types of baddeleyite-zircon intergrowths have to be considered (compiled in Table 4). Three of these types are not observed in our samples: (1) granular baddeleyite droplets can rim zircon that decomposed to baddeleyite $+\mathrm{SiO}_{2}$ as a result of impact shockwave heating (e.g., El Goresy, 1965; Wittmann et al., 2006). (2) The inversion of this reaction was found in a shergottite sample, where primary baddeleyite is often partially rimmed by polycrystalline zircon in the vicinity of impact melt (Moser et al., 2013; Darling et al., 2016). This is the only baddeleyitezircon intergrowth type where baddeleyite is affected by shockwave metamorphism (Moser et al., 2013; Darling et al., 2016). (3) Feather-like polycrystalline baddeleyite reaction rims on mantle-derived zircons in kimberlites were found to be the result of desilicification reactions (Kresten, 1973). These seven intergrowth types can occur in combination, complicating textural interpretation. Dating by SIMS or LA-ICP-MS provides the high spatial resolution that is required to unravel the age relationships of baddeleyite-zircon intergrowths. Alternatively, dissolution in hydrochloric acid alone may avoid including zircon domains in ID-TIMS baddeleyite analyses (e.g., Rioux et al., 2010).

\subsection{Interpreting intrusion ages from nonideal baddeleyite}

\subsubsection{Challenges in baddeleyite geochronology by SIMS}

Despite many examples of good agreement between SIMS and ID-TIMS data (e.g., the SIMS ${ }^{207} \mathrm{~Pb} /{ }^{206} \mathrm{~Pb}$ date agrees with the ID-TIMS ${ }^{207} \mathrm{~Pb} /{ }^{206} \mathrm{~Pb}$ and upper intercept dates of FP6D, the SIMS in situ dates agree with both ID-TIMS dates of S2E, and all dates of SL18 and FC-4b agree), some SIMS sessions yielded significantly deviating dates, notably in the case of grain mount sessions and/or ${ }^{206} \mathrm{~Pb} /{ }^{238} \mathrm{U}$ dates. Although SIMS dates of baddeleyite can be more accurate than ID-TIMS dates in certain cases (see Sect. 6.2.3 and 6.2.4), baddeleyite poses analytical challenges that are specific for in situ methods: beam overlap on adjacent phases and possible bias in the $\mathrm{U} / \mathrm{Pb}$ relative sensitivity calibration (RSC).

Small crystal sizes of baddeleyite $(<10 \mu \mathrm{m})$ often result in primary beam overlap on adjacent phases during SIMS sessions. This does not necessarily affect the accuracy of baddeleyite dates if the adjacent minerals are $\mathrm{U}$ and $\mathrm{Pb}$ free (e.g., chlorite), but otherwise, especially in the case of intergrowths with zircon and zirconolite, accuracy of baddeleyite dates can be severely affected. But even so, estimations of the baddeleyite crystallization ages are possible if the extents of potential resulting inaccuracies can be assessed. This requires knowledge about (1) the approximate U-Pb crystallization ages of baddeleyite and the contaminating phase we suppose that the zircon rims of SEIC samples formed at ca. 400 Ma during the Acadian Orogeny, being ca. $20 \%$ younger than SEIC baddeleyite, and that some of the zircon rims experienced $\mathrm{Pb}$ loss; (2) possible differences in $\mathrm{U}$ content of the involved minerals - baddeleyite tends to have the same (this study) or higher (Heaman and LeCheminant, 1993) U contents than zircon and lower U contents than zirconolite (Rasmussen and Fletcher, 2004); and (3) matrix effects that lead to different $\mathrm{U} / \mathrm{Pb}$ relative sensitivities. As observed from the RSC, baddeleyite ${ }^{206} \mathrm{~Pb} /{ }^{238} \mathrm{U}$ dates shift to younger ages when computed against a zircon RSC ( -54 to 
Table 4. Compilation of all known baddeleyite (Bad)-zircon ( $\mathrm{Zrn})$ intergrowth types and guideline for their interpretation.

\begin{tabular}{|c|c|c|c|c|c|}
\hline $\begin{array}{l}\text { Appearance in } \\
\text { BSE image }\end{array}$ & Type & $\begin{array}{l}\text { Common } \\
\text { textural features }\end{array}$ & $\begin{array}{l}\text { Age } \\
\text { relationship }\end{array}$ & Rock types & References \\
\hline & $\begin{array}{l}\text { Igneous Bad re- } \\
\text { placed by meta- } \\
\text { morphic Zrn }\end{array}$ & $\begin{array}{l}\text { Frosty or raspberry-like } \\
\text { Zrn rims or feather-like } \\
\text { Zrn coronas; pseudo- } \\
\text { morphism; irregular } \\
\text { crystal interfaces }\end{array}$ & $\mathrm{Bad}>\mathrm{Zrn}$ & $\begin{array}{l}\text { High- and low- } \\
\text { grade meta- } \\
\text { igneous rocks }\end{array}$ & $\begin{array}{l}\text { Heaman and } \\
\text { LeCheminant } \\
\text { (1993); Söderlund } \\
\text { et al. (2013); this } \\
\text { study }\end{array}$ \\
\hline (b) & $\begin{array}{l}\text { Late igneous } \\
\text { Zrn rim on } \\
\text { igneous Bad }\end{array}$ & $\begin{array}{l}\text { Euhedral Zrn rims; } \\
\text { straight interfaces with } \\
\text { Bad }\end{array}$ & $\begin{array}{l}\mathrm{Bad}>\mathrm{Zrn} \\
(\approx)\end{array}$ & $\begin{array}{l}\text { Igneous rocks } \\
\text { which record } \\
\text { the overstep of } \\
\mathrm{SiO}_{2} \text { oversatu- } \\
\text { ration }\end{array}$ & $\begin{array}{l}\text { Renna et al. } \\
(2011)\end{array}$ \\
\hline
\end{tabular}

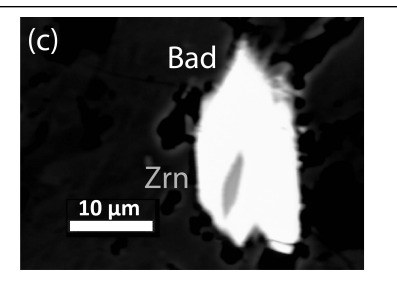

$\begin{array}{llll}\begin{array}{l}\text { Igneous Bad } \\ \text { with xenocrys- }\end{array} & \begin{array}{l}\text { Complete Bad mantle } \\ \text { around Zrn }\end{array} & \mathrm{Bad}<\mathrm{Zrn} & \begin{array}{l}\text { Gabbros; prob- } \\ \text { ably other ig- }\end{array}\end{array}$
tic Zrn incluneous rocks

sions (?)

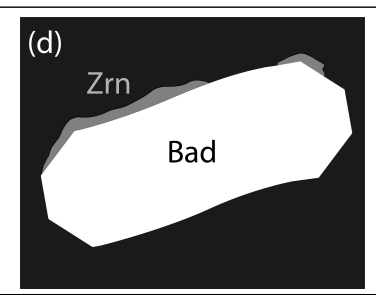

Bad with Z

Bad often deformed, with degraded crystallinity or disintegrated rim closed t impact melt pockets into granular droplets;

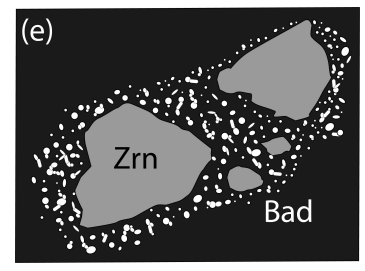

Zrn decomposition during impact melting

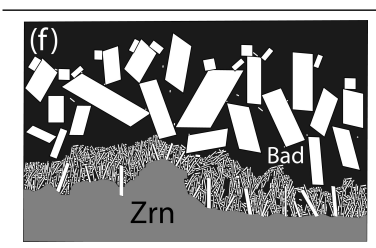

Desilification
Bad on mantle-
derived Zrn

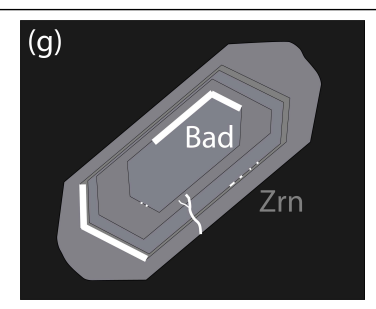

Altered igneous Zrn with secondary Bad inclusions
Bad $>$ Zrn Meteorites

Zrn rims discontinuous

up to a few $\mu \mathrm{m}$
Droplets of Bad or other $\mathrm{ZrO}_{2}$ polymorphs; Zrn often with deformation features similar to Bad in (d)

\section{Bad $<$ Zrn Impact glasses}

\section{El Goresy (1965); Wittmann et al. (2006)}

Feather-like Bad rim

(often intergrown with

diopside) on a Zrn

megacryst

$\begin{array}{lll}\operatorname{Bad}<\mathrm{Zrn} & \text { Kimberlites } & \text { Kresten } \\ (\approx) & & (1973) ; \text { Heaman } \\ & & \text { and LeCheminant } \\ & (1993)\end{array}$

Moser et al. (2013);

Darling et al.

(2016)

$\begin{array}{llll}\begin{array}{l}\text { Bad often arranged } \\ \text { along the Zrn zonation }\end{array} & \text { Bad }<\text { Zrn } & \begin{array}{l}\text { Altered igneous } \\ \text { rocks, includ- }\end{array} & \begin{array}{l}\text { Lewerentz et } \\ \text { al. (2019); this } \\ \text { or along cracks }\end{array} \\ & \begin{array}{l}\text { ing siliceous } \\ \text { rocks }\end{array} & \text { study }\end{array}$


$+3 \%$ total, $-23 \%$ average), and zircon dates become older vice versa $(+1 \%$ to $+121 \%,+43 \%$ average $)$. Similar bias results from baddeleyite-zirconolite beam overlap, although presently this bias cannot be quantified due to lack of wellcharacterized zirconolite reference materials. Notably, when SIMS baddeleyite analyses contain metamorphic zircon contributions, their younger age is partly compensated by the RSC bias, so their influence on data quality is less severe than in the cases where zircon is coeval or older than baddeleyite.

Precision and accuracy of SIMS ${ }^{206} \mathrm{~Pb} /{ }^{238} \mathrm{U}$ dates strongly depend on the quality of the RSC. Variable degrees of reverse discordance in different SIMS grain mount sessions of the same sample most likely reflect difficulties in quantification of matrix effects. RSC accuracy depends on numerous factors, but crystal orientation effects have been long recognized as particularly important for SIMS U-Pb dating of baddeleyite (Wingate and Compston, 2000). Although oxygen flooding of the sample chamber proved to be effective for reducing crystal orientation effects, residual bias remains (Schmitt et al., 2010; Li et al., 2010). In the case of grain mounts, tabular crystals will be preferentially oriented with their $\mathrm{c}$ axis parallel to the sample surface. This may be a cause of matrix mismatch in grain mount analyses, whereas in situ mounts, which lack reverse discordance in this study, are expected to have more random distributions of crystal orientations. Analysis of a sufficiently large number of crystals (> ca. 25) and randomizing crystal orientations of grain mounts may lead to more accurate SIMS ${ }^{206} \mathrm{~Pb} /{ }^{238} \mathrm{U}$ baddeleyite dates. However, crystal orientation effects, if present, would also be expected for the secondary reference baddeleyite FC-4b, which nevertheless yielded ${ }^{206} \mathrm{~Pb} /{ }^{238} \mathrm{U}$ dates in agreement with published ID-TIMS data (Schmitt et al., 2010), although it was analyzed during the same grain mount sessions as FP6D and S2E baddeleyite. Hence, other factors such as alteration may be more significant for the RSC than crystal orientation.

\subsubsection{Common $\mathrm{Pb}$ in $\mathrm{Zr}$-bearing minerals}

Ideal U-Pb mineral geochronometers exclude common $\mathrm{Pb}$ during crystallization, a behavior that baddeleyite, zircon and zirconolite approximately fulfill (e.g., Heaman and LeCheminant, 1993; Rasmussen and Fletcher, 2004). However, in our samples, all three minerals often contain abundant common $\mathrm{Pb}$, as evident from SIMS and ID-TIMS analyses of SEIC and CSMS (Tables 3 and S1-S6). Similar abundances of common $\mathrm{Pb}$ were also detected in baddeleyite from other mafic dikes (e.g., Olsson et al., 2011). Adjacent phases, surface contamination (SIMS), laboratory blank (IDTIMS) and mineral inclusions (SIMS and ID-TIMS) can be external sources of common $\mathrm{Pb}$, but steady ${ }^{204} \mathrm{~Pb}$ counting rates even in some SIMS analyses with the spot entirely on baddeleyite demonstrate that some amount of common $\mathrm{Pb}$ is intrinsic to these crystals. In the case of zircon, it is known that common $\mathrm{Pb}$ can be incorporated during alter- ation (e.g., Watson et al., 1997; Rayner et al., 2005; Geisler et al., 2007). By analogy, the interplay of radiation damage and interaction with fluids may trigger a similar process in baddeleyite and zirconolite. Alteration could also modify the chemical composition of baddeleyite and may therefore bias the RSC, but a correlation of ${ }^{206} \mathrm{~Pb} /{ }^{238} \mathrm{U}$ date and common$\mathrm{Pb}$ content is detectable only for sample FP7G, which also shows a correlation of common- $\mathrm{Pb}$ content and the (RSCindependent) ${ }^{207} \mathrm{~Pb} /{ }^{206} \mathrm{~Pb}$ date. Moreover, common- $\mathrm{Pb}$ contents of baddeleyite in FP7G and FP12A increase with decreasing U content, making it difficult to explain common$\mathrm{Pb}$ incorporation with radiation damage, unless $\mathrm{U}$ was mobilized as well. Uranium mobilization can cause normal or reverse discordance and may therefore be detectable by further ID-TIMS analyses. Furthermore, baddeleyite and zircon can be expected to alter differently, as baddeleyite is more resistant to radiation damage (Schaltegger and Davies, 2017). Oxygen isotope analysis by SIMS has been suggested as a tool to detect baddeleyite alteration (Davies et al., 2018), although its routine use is still in its infancy. Zirconolite, which only allows for ${ }^{207} \mathrm{~Pb} /{ }^{206} \mathrm{~Pb}$ dating (Rasmussen and Fletcher, 2004), shows high common- $\mathrm{Pb}$ abundances in sample FP7G (45\%-93\% radiogenic ${ }^{206} \mathrm{~Pb}$ ), being therefore unsuited as a geochronometer for altered samples.

\subsubsection{Baddeleyite discordance}

Although volume diffusion of $\mathrm{Pb}$ in baddeleyite is thought to be extremely slow (Heaman and LeCheminant, 2000), baddeleyite analyses often show a few percent of discordance. Naturally observed discordance patterns range from linear and complex arrays to uniform clusters beneath concordia (e.g., Söderlund et al., 2013; Schaltegger and Davies, 2017; Heaman and LeCheminant, 2000; Ibañez-Mejia and Tissot, 2019). This underscores that discordance is not always created by the same mechanism, and it is crucial for age interpretation to identify the correct discordance mechanism(s) in the specific sample by means of the discordance pattern (Fig. 10). If contributions from metamorphic zircon rims have caused discordance, a three-component mixing model can be applied, with end-members defined by (1) the igneous crystallization age of baddeleyite, (2) metamorphic formation of zircon, and (3) recent $\mathrm{Pb}$ loss of zircon and/or baddeleyite (Söderlund et al., 2013). The oldest ${ }^{207} \mathrm{~Pb} /{ }^{206} \mathrm{~Pb}$ date would then yield a minimum estimate of 1 . In contrast, ${ }^{231} \mathrm{~Pa}$ excess would influence only the ${ }^{207} \mathrm{~Pb} /{ }^{235} \mathrm{U}$ decay system, making ${ }^{206} \mathrm{~Pb} /{ }^{238} \mathrm{U}$ ages most accurate (Amelin and Zaitsev, 2002; Crowley and Schmitz, 2009) and vice versa in the case of ${ }^{222} \mathrm{Rn}$ loss (Heaman and LeCheminant, 2000). Pb loss due to alpha recoil or fast pathway diffusion (e.g., along twin planes) affects both systems similarly, making ${ }^{207} \mathrm{~Pb} /{ }^{206} \mathrm{~Pb}$ ages most accurate (Davis and Davis, 2018).

Metamorphic zircon overgrowth was absent in baddeleyite used for ID-TIMS analysis of S2E and SL18. Even in FP6D, where it is petrographically evident, the ID-TIMS data ap- 


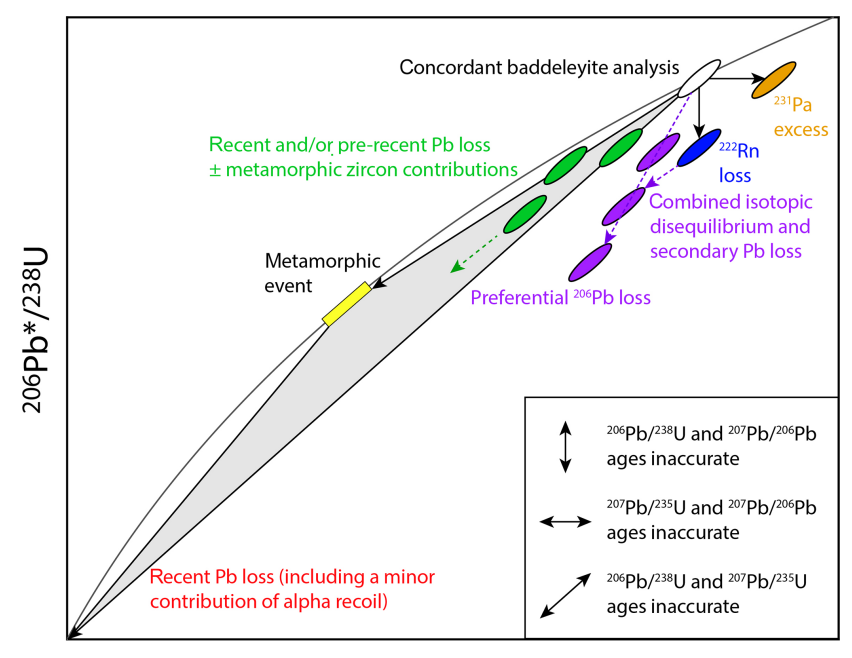

$207 \mathrm{~Pb}^{*} / 235 \mathrm{U}$

Figure 10. Schematic model of the consequences of different discordance mechanisms on the isotopic composition of baddeleyite.

pear to be free of a significant isotopic component of metamorphic zircon. This confirms that baddeleyite and zircon can be separated successfully with the method of Rioux et al. (2010), using only hydrochloric acid for dissolution. Consequently, discordance in our samples should be attributed rather to baddeleyite itself than to zircon intergrowths. Our ID-TIMS analyses show linear arrays that are typical for varying degrees of recent $\mathrm{Pb}$ loss. The portion of radiogenic $\mathrm{Pb}$ lost by alpha recoil can be predicted based on crystal shapes (Davis and Davis, 2018) and is generally $<0.3 \%$ for the crystals of this study. However, $\mathrm{Pb}$ loss indicated for our samples exceeds this extent often by more than 1 order of magnitude (Table 3). Hence alpha recoil can explain only a small part of the discordance observed for FP6D, S2E and SL18, depending on the $\mathrm{U}$ zonation of the crystals. Fast pathway and/or volume diffusion is therefore likely to dominate baddeleyite discordance here. The radiation dose does not seem to be crucial: except for the in situ session of S2E, negative correlations between $\mathrm{U}$ content and ${ }^{206} \mathrm{~Pb} /{ }^{238} \mathrm{U}$ dates appear to be absent in SIMS and ID-TIMS data of our samples (cf. Söderlund et al., 2013).

Intriguingly, the discordia trends for samples FP6D and S2E have negative lower intercepts and show a positive correlation of the ${ }^{207} \mathrm{~Pb} /{ }^{206} \mathrm{~Pb}$ date with the percentage of discordance (Fig. 8). Similar discordance patterns have been observed from baddeleyite ID-TIMS analyses of the Duluth gabbro (Hoaglund, 2010; Ibañez-Mejia and Tissot, 2019) which plot essentially within the concordia error swath, but yielded older ${ }^{207} \mathrm{~Pb} /{ }^{206} \mathrm{~Pb}$ dates, younger ${ }^{206} \mathrm{~Pb} /{ }^{238} \mathrm{U}$ dates and undistinguishable ${ }^{207} \mathrm{~Pb} /{ }^{235} \mathrm{U}$ dates compared to coexisting zircon. These studies interpreted ${ }^{231} \mathrm{~Pa}$ excess to be responsible for this pattern, which cannot be excluded as evidence for modest amounts of excess ${ }^{231} \mathrm{~Pa}$ was recently obtained from young baddeleyite (Sun et al., 2020). However, the negative lower intercepts for our Newfoundland samples would require that the magnitude of ${ }^{231} \mathrm{~Pa}$ excess increases with discordance, which is difficult to rationalize. For the Duluth gabbro analyses, the overlap of baddeleyite and zircon ${ }^{207} \mathrm{~Pb} /{ }^{235} \mathrm{U}$ dates is impossible to produce with ${ }^{231} \mathrm{~Pa}$ excess alone. We therefore propose preferential loss of ${ }^{206} \mathrm{~Pb}$, possibly due to ${ }^{222} \mathrm{Rn}$ mobility, as a more likely explanation of these peculiar patterns (see Heaman and LeCheminant, 2000), as such excess ${ }^{206} \mathrm{~Pb}$ loss could simply increase with overall Pb loss (see Sect. S6 for more details). Negative lower intercepts have rarely been reported in previous baddeleyite dating studies, suggesting that they are either caused by a rare process or are often masked by uncertainties and/or additional discordance mechanisms.

Our data also imply that baddeleyite rims are more strongly affected by $\mathrm{Pb}$ loss than cores. The ID-TIMS data of SL18 (Fig. 9c) show younger ${ }^{206} \mathrm{~Pb} /{ }^{238} \mathrm{U}$ dates for the smallest crystals, which have larger surface to volume ratios than the larger crystals. Furthermore, the ID-TIMS analyses of large SL18 baddeleyite yielded younger ${ }^{206} \mathrm{~Pb} /{ }^{238} \mathrm{U}$ dates than the SIMS analyses (Table 3 vs. Table S6). The SIMS spots were typically placed in the centers of the grains, avoiding the apparently less discordant rims, whereas dissolution of the plucked grains for ID-TIMS analysis included them, resulting in more discordant ID-TIMS analyses. Admittedly, it cannot be excluded that SIMS ${ }^{206} \mathrm{~Pb} /{ }^{238} \mathrm{U}$ data of the relatively pristine SL18 baddeleyite may be also affected by RSC bias, similar to the altered Newfoundland samples. However, this concern is irrelevant for the ${ }^{207} \mathrm{~Pb} /{ }^{206} \mathrm{~Pb}$ data, which agree within error between SIMS and ID-TIMS for SL18, but ${ }^{207} \mathrm{~Pb} /{ }^{206} \mathrm{~Pb}$ dates from the more discordant Newfoundland samples tend to be older for ID-TIMS than for SIMS. This may imply that baddeleyite rims in FP6D have undergone preferential ${ }^{206} \mathrm{~Pb}$ loss, which would drive the more discordant ID-TIMS analyses towards older ${ }^{207} \mathrm{~Pb} /{ }^{206} \mathrm{~Pb}$ dates. In any case, fast pathway and/or volume diffusion can both explain intensified $\mathrm{Pb}$ loss from crystal rims, but to differentiate between these processes, both the $\mathrm{U}$ zonation within the crystals and the post-emplacement thermal history of the samples are not sufficiently known.

\subsubsection{Implications for baddeleyite dating approaches}

Targeting the least altered and most coarse-grained samples in the field is highly advantageous for recovery of pristine baddeleyite which often yields concordant ages. However, as the examples of SEIC and CSMS rocks show, alteration can be ubiquitous in certain geologic units, so that usage of texturally complex, discordant baddeleyite is inevitable. But even baddeleyite from unaltered samples, such as SL18, often shows evidence for minor $\mathrm{Pb}$ loss (see also Söderlund et al., 2015). With $\mathrm{Pb}$ loss as a dominant discordance mechanism, ${ }^{206} \mathrm{~Pb} /{ }^{238} \mathrm{U}$ dates of baddeleyite often underestimate intrusion ages, whereas ${ }^{207} \mathrm{~Pb} /{ }^{206} \mathrm{~Pb}$ dates are more accurate. In the case of SIMS, another advantage 
of ${ }^{207} \mathrm{~Pb} /{ }^{206} \mathrm{~Pb}$ dates is their independence from the RSC. This favors the use of ${ }^{207} \mathrm{~Pb} /{ }^{206} \mathrm{~Pb}$ rather than ${ }^{206} \mathrm{~Pb} /{ }^{238} \mathrm{U}$ ages even for Phanerozoic baddeleyite, in spite of its typically lower precision. For Mesozoic samples such as SL18, however, comparatively low precisions of SIMS data make it difficult to use ${ }^{207} \mathrm{~Pb} /{ }^{206} \mathrm{~Pb}$ dates meaningfully, although improved ${ }^{207} \mathrm{~Pb} /{ }^{206} \mathrm{~Pb}$ precisions have been achieved with a multicollection SIMS method (Li et al., 2009). Another limitation for ${ }^{207} \mathrm{~Pb} /{ }^{206} \mathrm{~Pb}$ dates is possible bias by preferential ${ }^{206} \mathrm{~Pb}$ loss, as suggested by the correlation of ${ }^{207} \mathrm{~Pb} /{ }^{206} \mathrm{~Pb}$ dates with the percentage of discordance (Fig. 8). If this bias is important, the ${ }^{207} \mathrm{~Pb} /{ }^{206} \mathrm{~Pb}$ dates of the least discordant analyses are most accurate, and more discordant analyses should be excluded from weighted mean calculations. Alternatively, if the excess ${ }^{206} \mathrm{~Pb}$ loss is a linear function of total $\mathrm{Pb}$ loss, upper intercept dates are the most accurate. This can be shown for sample FP6D, where the upper intercept date from ID-TIMS $(499 \pm 5 \mathrm{Ma})$ and the ${ }^{207} \mathrm{~Pb} /{ }^{206} \mathrm{~Pb}$ date from SIMS (497 $\pm 7 \mathrm{Ma}$ ) are indistinguishable but most of the ID-TIMS ${ }^{207} \mathrm{~Pb} /{ }^{206} \mathrm{~Pb}$ dates are considerably older (504$530 \mathrm{Ma}$, Table 3, Fig. 8). If baddeleyite cores are less discordant than rims, the cores should be preferentially targeted for analysis, which is easier to achieve with SIMS. In the case of ID-TIMS, mechanical abrasion is potentially helpful in this respect, and there are documented cases where discordance was reduced by mechanical abrasion (e.g., Corfu and Lightfoot, 1996; cf. Greenough et al., 1993). Alternatively, baddeleyite cores can be cut out with a focused ion beam before ID-TIMS analysis (White et al., 2020).

\subsubsection{Intrusion ages of the SEIC, CSMS and FLC}

Stratigraphic constraints require that the SEIC is coeval with the Cambrian volcano-sedimentary succession on the western Avalon Peninsula (Sect. 2.1). Trilobite biostratigraphy suggests that the age span of deposition of the Manuels River Formation roughly equals that of the Drumian stage (Hildenbrand, 2016; Austermann, 2016), which is currently calibrated from 504.5 to $500.5 \mathrm{Ma}$ with uncertainties on these bounds of ca. $2 \mathrm{Ma}$ (Peng et al., 2012). The occurrence of pillow lavas in the Chamberlain's Brook Formation and Elliot Cove formation expands the age range of Cambrian volcanism on the Avalon Peninsula to both pre- and postDrumian (Fig. 2). Our SIMS and ID-TIMS data are thus in good agreement with these stratigraphic constraints. We regard the ID-TIMS concordia upper intercept date of FP6D $(498.7 \pm 4.5 \mathrm{Ma})$ as the best available estimate of the intrusion age of the corresponding feeder pipe, as it is more likely unbiased by the sample-specific baddeleyite discordance mechanisms than the ${ }^{206} \mathrm{~Pb} /{ }^{238} \mathrm{U}$ and ${ }^{207} \mathrm{~Pb} /{ }^{206} \mathrm{~Pb}$ dates. As indicated by the stratigraphic distribution of volcanic rocks, the other feeder pipes may be significantly older and/or younger, but this first radiometric age for the SEIC indicates that SEIC magmatism clearly predates the opening of the Rheic Ocean (see Sect. 2).

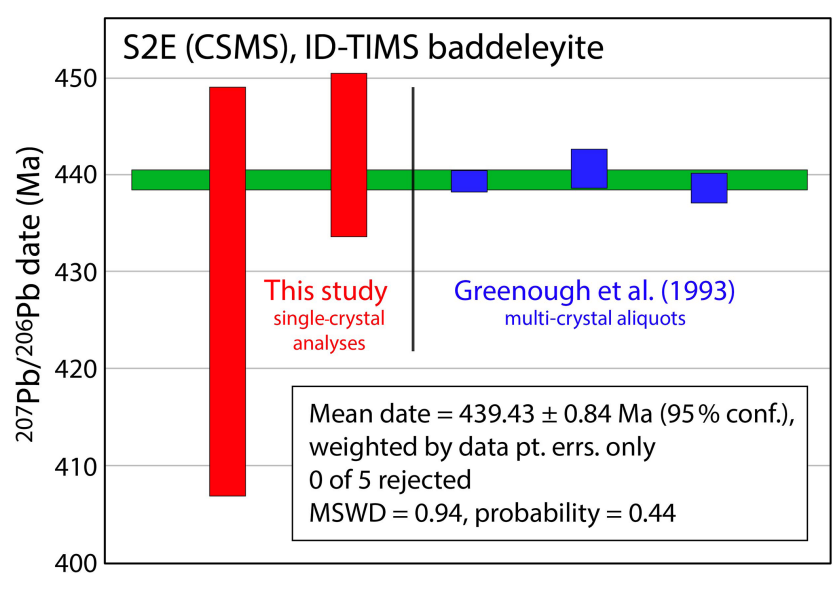

Figure 11. Recalculated age for the Cape St. Mary's sills using only the ID-TIMS data of Greemough et al. (1993) and this study which are $<3 \%$ discordant.

For the CSMS, zircon from granophyre sample S2C is considerably altered and the degree of secondary $\mathrm{Pb}$ loss is often very large (Sect. S4), limiting its use for geochronology. Baddeleyite from sample S2E, although potentially also altered, better preserves the igneous age. Our ID-TIMS ${ }^{207} \mathrm{~Pb} /{ }^{206} \mathrm{~Pb}$ baddeleyite date $(444.1 \pm 4.4 \mathrm{Ma})$ agrees within error with that of Greenough et al. (1993), and the samples of both studies are derived from the same granophyric dike (John D. Greenough, personal communication, 2019). Greenough et al. (1993) analyzed bulk separates of baddeleyite, and the large number of crystals per aliquot in their analyses enhanced precision due to stronger $\mathrm{Pb}$ signals, but may have obscured the discordance patterns that we observed in our single-crystal analyses. Combining the data of both studies, we regard a weighted mean ID-TIMS ${ }^{207} \mathrm{~Pb} /{ }^{206} \mathrm{~Pb}$ age of $439.4 \pm 0.8 \mathrm{Ma}(95 \%$ conf.; MSWD $=0.94$; Fig. 11 ) as the best available estimate of the intrusion age of the Lance Cove sill, using only the analyses with $<3 \%$ discordance to minimize bias due to possible preferential ${ }^{206} \mathrm{~Pb}$ loss. If this bias is significant even for the least discordant analyses, this ${ }^{207} \mathrm{~Pb} /{ }^{206} \mathrm{~Pb}$ date may be an overestimate, but the ID-TIMS upper intercept date of $437 \pm 8 \mathrm{Ma}$, which would be more accurate in this case, does not lead to a better age estimate due to inferior precision. The date that we report does not rule out the possibility that other sills of Cape St. Mary's are significantly older or younger.

For the FLC, our new ID-TIMS and SIMS data suggest that the intrusive age based on a weighted mean ${ }^{206} \mathrm{~Pb} /{ }^{238} \mathrm{U}$ date reported in Callegaro et al. (2017) from large baddeleyite crystals is likely too young and reflects some degree of $\mathrm{Pb}$ loss. The small baddeleyite crystals from SL18 yielded younger ID-TIMS ${ }^{206} \mathrm{~Pb} /{ }^{238} \mathrm{U}$ dates due to more intense $\mathrm{Pb}$ loss, likely due to fast pathway or volume diffusion. Therefore, we regard the weighted mean ${ }^{207} \mathrm{~Pb} /{ }^{206} \mathrm{~Pb}$ ID-TIMS date $(201.07 \pm 0.64 \mathrm{Ma})$ as the best estimate for the intrusion age of SL18. This age is in agreement with the SIMS 
dates and all other age constraints from both the FLC and the CAMP (Davies et al., 2017; Callegaro et al., 2017). This new age does not change the overall interpretations of Callegaro et al. (2017). The good agreement of the SIMS and ID-TIMS dates from sample SL18 validates that baddeleyite dating by SIMS, which has been applied so far mostly for Precambrian and early Paleozoic samples (e.g., Schmitt et al., 2010), can also yield accurate ages for Mesozoic samples.

\section{Conclusions}

Based on new and published microtextural observations, at least seven different types of baddeleyite-zircon intergrowths can be identified. Secondary baddeleyite inclusions in zircon can also form during low-temperature alteration. Furthermore, we interpret a previously undocumented texture as xenocrystic zircon cores mantled by igneous baddeleyite overgrowths.

SIMS ${ }^{206} \mathrm{~Pb} /{ }^{238} \mathrm{U}$ data, at least from grain mounts, show bias in the $\mathrm{U} / \mathrm{Pb}$ relative sensitivity calibration, possibly due to crystal orientation effects and/or alteration.

Unusually high common- $\mathrm{Pb}$ contents in baddeleyite are evident from SIMS and ID-TIMS data of the same crystals and probably a consequence of alteration.

For our samples, we identified secondary $\mathrm{Pb}$ loss, due to fast pathway and/or volume diffusion, as the dominant discordance mechanism. Correlations between ${ }^{207} \mathrm{~Pb} /{ }^{206} \mathrm{~Pb}$ dates and the degree of discordance imply that there may be a component of preferential ${ }^{206} \mathrm{~Pb}$ loss, possibly due to ${ }^{222} \mathrm{Rn}$ mobility. Baddeleyite rims appear to be more affected by $\mathrm{Pb}$ loss than cores.

Any kind of $\mathrm{Pb}$ loss makes ${ }^{207} \mathrm{~Pb} /{ }^{206} \mathrm{~Pb}$ ages more reliable than ${ }^{206} \mathrm{~Pb} /{ }^{238} \mathrm{U}$ ages, even for Phanerozoic baddeleyite. In the case of preferential ${ }^{206} \mathrm{~Pb}$ loss, the most accurate age is either the concordia upper intercept date or the weighted mean ${ }^{207} \mathrm{~Pb} /{ }^{206} \mathrm{~Pb}$ date of the least discordant analyses. Improved concordance of baddeleyite dates may be achieved when preferentially targeting the less discordant crystal cores, either by SIMS spot analysis, or possibly by applying mechanical abrasion prior to ID-TIMS analysis.

We present new and refined intrusion ages for the Spread Eagle Intrusive Complex, Newfoundland (498.7 $\pm 4.5 \mathrm{Ma}$, ID-TIMS concordia upper intercept), which formed during rifting before the opening of the Rheic Ocean, as well as for Cape St. Mary's sills, Newfoundland (444.1 $\pm 4.4 \mathrm{Ma}$, ID-TIMS weighted mean ${ }^{207} \mathrm{~Pb} /{ }^{206} \mathrm{~Pb}$ date of the least discordant analyses), and the Freetown Layered Complex, Sierra Leone $(201.07 \pm 0.64 \mathrm{Ma}$, ID-TIMS weighted mean ${ }^{207} \mathrm{~Pb} /{ }^{206} \mathrm{~Pb}$ date).

Data availability. All research data are given in Table 3 and in the supplementary tables of this article.
Supplement. The supplement related to this article is available online at: https://doi.org/10.5194/gchron-2-187-2020-supplement.

Author contributions. This study is partly based on the MSc thesis of JEP, supervised by AKS. GA and AH applied for funding and helped with fieldwork. SIMS analyses were performed by JEP (SEIC, CSMS), AKS and KRC (SL18). ID-TIMS analyses were performed by KRC (SEIC, CSMS) and JHFLD (SL18). Geochronological interpretations developed from discussions between JEP, KRC and AKS with additions by JHFLD. JEP wrote the article with support from all co-authors.

Competing interests. The authors declare that they have no conflict of interest.

Acknowledgements. Ilona Fin and Oliver Wienand prepared thin sections and epoxy mounts. Robert B. Trumbull (Helmholtz Centre Potsdam - GFZ Potsdam) contributed whole-rock geochemical data (see Table S7, Figs. S10-S12).

Financial support. This project is funded by the Klaus Tschira Foundation (03.131.2017 Förderung von Abschlussarbeiten (MSc und BSc) in Verbindung mit Projekt 00.272.2015 "Kambrium von Avalonia mit Schwerpunkt Ostneufundland"). Further support came from the German Research Foundation (DFG Scientific Instrumentation and Information Technology program). Kevin R. Chamberlain was partially supported from Mega-Grant 14.Y26.31.0012 and RNF grant 18-17-00240 of the government of the Russian Federation.

Review statement. This paper was edited by Daniela Rubatto and reviewed by Ulf Söderlund and one anonymous referee.

\section{References}

Amelin, Y. and Zaitsev, A. N.: Precise geochronology of phoscorites and carbonatites: The critical role of U-series disequilibrium in age interpretations, Geochim. Cosmochim. Ac., 66, 2399-2419, 2002.

Anthony, J. W., Bideaux, R. A., Bladh, K. W., and Nichols, M. C. (Eds.): Handbook of Mineralogy. Mineralogical Society of America, Chantilly, VA 20151-1110, USA, 2001.

Aranovich, L. Y., Zinger, T. F., Bortnikov, N. S., Sharkov, E. V., and Antonov, A. V.: Zircon in gabbroids from the axial zone of the Mid-Atlantic Ridge, Markov Deep, $6^{\circ} \mathrm{N}$ : correlation of geochemical features with petrogenetic processes, Petrology, 21, 1$15,2013$.

Aranovich, L. Y., Bortnikov, N. S., Zinger, T. F., Borisovskiy, S. E., Matrenichev, V. A., Pertsev, A. N., Sharkov, E. V., and Skolotnev, S. G.: Morphology and impurity elements of zircon in the oceanic lithosphere at the Mid-Atlantic ridge axial zone $\left(6^{\circ}-\right.$ $\left.13^{\circ} \mathrm{N}\right)$ : Evidence of specifics of magmatic crystallization and postmagmatic transformations, Petrology, 25, 339-364, 2017. 
Austermann, G.: Sedimentology and depositional environment of the middle Cambrian Manuels River Formation in the type locality at Conception Bay South, Newfoundland, Canada, Unpublished PhD thesis, Heidelberg University, 356 pp., 2016.

Barth, M. G., Rudnick, R. L., Carlson, R. W., Horn, I., and McDonough, W. F.: Re-Os and U-Pb geochronological constraints on the eclogite-tonalite connection in the Archean Man Shield, West Africa, Precambrian Res., 118, 267-283, 2002.

Blackburn, T. J., Olsen, P. E., Bowring, S. A., McLean, N. M., Kent, D. V., Puffer, J., McHone, G., Rasburry, E. T., and Et-Touhami, M.: Zircon U-Pb geochronology links the end-Triassic extinction with the Central Atlantic Magmatic Province, Science, 340, 941945, 2013.

Boehnke, P., Watson, E. B., Trail, D., Harrison, T. M., and Schmitt, A. K.: Zircon saturation re-revisited, Chem. Geol., 351, 324-334, 2013.

Callegaro, S., Marzoli, A., Bertrand, H., Blichert-Toft, J., Reisberg, L., Cavazzini, G., Jourdan, F., Davies, J. H. F. L., Parisio, L., Bouchet, R., Paul, A., Schaltegger, U., and Chiaradia, M.: Geochemical Constraints Provided by the Freetown Layered Complex (Sierra Leone) on the Origin of High-Ti Tholeiitic CAMP Magmas, J. Petrol., 58, 1811-1840, 2017.

Chamberlain, K. R., Schmitt, A. K., Swapp, S. M., Harrison, T. M., Swoboda-Colberg, N., Bleeker, W., Peterson, T. D., Jefferson, C. W., and Khudoley, A. K.: In situ U-Pb SIMS (IN-SIMS) microbaddeleyite dating of mafic rocks: Method with examples, Precambrian Res., 183, 379-387, 2010.

Cocks, L. R. M., McKerrow, W. S., and van Staal, C. R.: The margins of Avalonia, Geol. Mag., 134, 627-636, 1997.

Corfu, F. and Lightfoot, P. C.: U-Pb geochronology of the sublayer environment, Sudbury Igneous Complex, Ontario, Econ. Geol., 91, 1263-1269, 1996.

Corfu, F., Hanchar, J. M., Hoskin, P. W., and Kinny, P.: Atlas of zircon textures, Rev. Mineral. Geochem., 53, 469-500, 2003.

Crowley, J. L. and Schmitz, M. D.: A precise comparison of U$\mathrm{Pb}$ dates from baddeleyite and zircon: evidence for excess ${ }^{207} \mathrm{~Pb}$ in baddeleyite. Eos, Transactions, American Geophysical Union, 90, V53B-06, 2009.

Darling, J. R., Moser, D. E., Barker, I. R., Tait, K. T., Chamberlain, K. R., Schmitt, A. K., and Hyde, B. C.: Variable microstructural response of baddeleyite to shock metamorphism in young basaltic shergottite NWA 5298 and improved U-Pb dating of Solar System events, Earth Planet. Sc. Lett., 444, 1-12, 2016.

Davies, J. H. F. L., Marzoli, A., Bertrand, H., Youbi, N., Ernesto, M., and Schaltegger, U.: End-Triassic mass extinction started by intrusive CAMP activity, Nat. Commun., 8, 1-8, 2017.

Davies, J. H. F. L., Stern, R. A., Heaman, L. M., Moser, D. E., Walton, E. L., and Vennemann, T.: Evaluating baddeleyite oxygen isotope analysis by secondary ion mass spectrometry (SIMS), Chem. Geol., 479, 113-122, 2018.

Davis, W. J. and Davis, D. W.: Alpha Recoil Loss of Pb from Baddeleyite Evaluated by High-Resolution Ion Microprobe (SHRIMP II) Depth Profiling and Numerical Modeling: Implications for the Interpretation of U-Pb Ages in Small Baddeleyite Crystals, in: Microstructural Geochronology: Planetary Records Down to Atom Scale, edited by: Moser, D., Corfu, F., Reddy, S., Darling, J., and Tait, K., John Wiley \& Sons, Inc., Hoboken, NJ, Geophysical Monograph 232, 247-259, 2018.
Davis, D. W. and Sutcliffe, R. H.: U-Pb ages from the Nipigon plate and northern Lake Superior, Geol. Soc. Am. Bull., 96, 15721579, 1985.

El Goresy, A.: Baddeleyite and its significance in impact glasses, J. Geophys. Res., 70, 3453-3456, 1965.

Fletcher, T. P.: Bedrock geology of the Cape St. Mary's Peninsula, Southwest Avalon Peninsula, Newfoundland (includes parts of NTS sheets 1M/1, 1N/4, 1L/16 and 1K13), Government Newfoundland and Labrador, Geological Survey, Department of Natural Resources, St. John's, 06-02, 117 pp., 2006.

Geisler, T., Schaltegger, U., and Tomaschek, F.: Re-equilibration of Zircon in Aqueous Fluids and Melts, Elements, 3, 43-50, 2007.

Greenough, J. D.: Petrology and geochemistry of Cambrian volcanic rocks from the Avalon Zone in Newfoundland and New Brunswick. Unpublished PhD thesis, Memorial University of Newfoundland, 487 pp., 1984.

Greenough, J. D. and Papezik, V. S.: Chloritization and carbonatization of Cambrian volcanic rocks in eastern Newfoundland and southern New Brunswick, Canada, Chem. Geol., 53, 53-70, 1985a.

Greenough, J. D. and Papezik, V. S.: Petrology and geochemistry of Cambrian volcanic rocks from the Avalon Peninsula, Newfoundland, Can. J. Earth Sci., 22, 1594-1601, 1985b.

Greenough, J. D. and Papezik, V. S.: Acado-Baltic volcanism in eastern North America and western Europe: Implications for Cambrian tectonism, Maritime Sediments and Atlantic Geology, 22, 240-251, 1986a.

Greenough, J. D. and Papezik, V. S.: Volatile control of differentiation in sills from the Avalon Peninsula, Newfoundland, Canada, Chem. Geol., 54, 217-236, 1986 b.

Greenough, J. D., Kamo, S. L., and Krogh, T. E.: A Silurian U-Pb age for the Cape St. Mary's sills, Avalon Peninsula, Newfoundland, Canada: implications for Silurian orogenesis in the Avalon Zone, Can. J. Earth Sci., 30, 1607-1612, 1993.

Harrison, T. M. and Watson, E. B.: Kinetics of zircon dissolution and zirconium diffusion in granitic melts of variable water content, Contrib. Mineral. Petr., 84, 66-72, 1983.

Heaman, L. M.: The application of U-Pb geochronology to mafic, ultramafic and alkaline rocks: an evaluation of three mineral standards, Chem. Geol., 261, 43-52, 2009.

Heaman, L. M. and LeCheminant, A. N.: Paragenesis and U-Pb systematics of baddeleyite ( $\mathrm{ZrO} 2)$, Chem. Geol., 110, 95-126, 1993.

Heaman, L. M. and LeCheminant, A. N.: Anomalous U-Pb systematics in mantle-derived baddeleyite xenocrysts from Ile Bizard; evidence for high temperature radon diffusion?, Chem. Geol., 172, 77-93, 2000.

Hildenbrand, A.: Agnostoid trilobites and biostratigraphy of the middle Cambrian Manuels River Formation in the type locality at Conception Bay South, Newfoundland, Canada, Unpublished $\mathrm{PhD}$ thesis, Heidelberg University, 111 pp., 2016.

Hoaglund, S. A.: U-Pb geochronology of the Duluth Complex and related hypabyssal intrusions: investigating the emplacement history of a large multiphase intrusive complex related to the $1.1 \mathrm{Ga}$ Midcontinent Rift, Unpublished MSc thesis, University of Minnesota, 103 pp., 2010.

Hodych, J. P. and Buchan, K. L.: Palaeomagnetism of the ca. 440 Ma Cape St Mary's sills of the Avalon Peninsula of New- 
foundland: implications for Iapetus Ocean closure, Geophys. J. Int., 135, 155-164, 1998.

Hutchinson, R. D.: Cambrian stratigraphy and trilobite faunas of Southeastern Newfoundland, Geological Survey of Canada Bulletin, 88, 1-156, 1962.

Ibañez-Mejia, M. and Tissot, F. L.: Extreme Zr stable isotope fractionation during magmatic fractional crystallization, Science Advances, 5, eaax8648, https://doi.org/10.1126/sciadv.aax8648, 2019.

King, A. F.: Geology of the Avalon Peninsula, Report 90-2, Newfoundland: Parts of $1 \mathrm{~K}, 1 \mathrm{M}, 1 \mathrm{~N}$ and $2 \mathrm{C}$, Government of Newfoundland and Labrador, Geological Survey, Department of Mines and Energy, St. John's, 1988.

Kresten, P.: The coating of kimberlitic zircons: a preliminary study, in: Lesotho Kimberlites, edited by: Nixon, P. H., Lesotho National Development Corp., Maseru, 220-223, 1973.

Lewerentz, A., Harlov, D. E., Scherstén, A., and Whitehouse, M. J.: Baddeleyite formation in zircon by Ca-bearing fluids in silicasaturated systems in nature and experiment: resetting of the U$\mathrm{Pb}$ geochronometer, Contrib. Mineral. Petr., 174, 64, 2019.

Li, Q.-L., Li, X.-H., Liu, Y., Tang, G.-Q., Yang, J.-H., and Zhu, W.G.: Precise $\mathrm{U}-\mathrm{Pb}$ and $\mathrm{Pb}-\mathrm{Pb}$ dating of Phanerozoic baddeleyite by SIMS with oxygen flooding technique, J. Anal. Atom. Spectrom., 25, 1107-1113, 2010.

Li, X.-H., Liu, Y., Li, Q. L., Guo, C. H., and Chamberlain, K. R.: Precise determination of Phanerozoic zircon $\mathrm{Pb} / \mathrm{Pb}$ age by multicollector SIMS without external standardization, Geochem. Geophy. Geosy., 10, Q04010, https://doi.org/10.1029/2009GC002400, 2009.

Linnemann, U., Pereira, F., Jeffries, T. E., Drost, K., and Gerdes, A.: The Cadomian Orogeny and the opening of the Rheic Ocean: the diacrony of geotectonic processes constrained by LA-ICP-MS $\mathrm{U}-\mathrm{Pb}$ zircon dating (Ossa-Morena and Saxo-Thuringian Zones, Iberian and Bohemian Massifs), Tectonophysics, 461, 21-43, 2008.

Linnemann, U., Herbosch, A., Liégeois, J. P., Pin, C., Gärtner, A., and Hofmann, M.: The Cambrian to Devonian odyssey of the Brabant Massif within Avalonia: A review with new zircon ages, geochemistry, Sm-Nd isotopes, stratigraphy and palaeogeography, Earth-Sci. Rev., 112, 126-154, 2012.

Ludwig, K. R.: PBDAT for MS-DOS, a computer program for IBM$\mathrm{PC}$ compatibles for processing raw $\mathrm{Pb}-\mathrm{U}-\mathrm{Th}$ isotope data, version 1.24, Open-File Report, U.S. Geological Survey, 88-542, 1988.

Ludwig, K. R.: Isoplot 3.00: A geochronological toolkit for Microsoft Excel, Berkeley Geochronology Center Special Publication, 4, 70 pp., 2003.

Lumpkin, G. R.: Physical and chemical characteristics of baddeleyite (monoclinic zirconia) in natural environments: an overview and case study, J. Nucl. Mater., 274, 206-217, 1999.

McCartney, W. D.: Whitbourne map-area, Newfoundland, Ottawa, Geologica Survey of Canada Memoir, 341, 133 pp., 1967.

Moser, D. E., Chamberlain, K. R., Tait, K. T., Schmitt, A. K., Darling, J. R., Barker, I. R., and Hyde, B. C.: Solving the Martian meteorite age conundrum using micro-baddeleyite and launchgenerated zircon, Nature, 499, 454-457, 2013.

Murphy, J. B., Keppie, J. D., Dostal, J., and Nance, R. D.: Neoproterozoic-early Paleozoic evolution of Avalonia, Geol. S. Am. S., 336, 253-266, 1999.
Murphy, J. B., Gutierrez-Alonso, G., Nance, R. D., FernandezSuarez, J., Keppie, J. D., Quesada, C., Strachan, R. A., and Dostal, J.: Origin of the Rheic Ocean: Rifting along a Neoproterozoic suture?, Geology, 34, 325-328, 2006.

O’Brien, S. J., Dunning, G. R., Dubé, B., O’Driscoll, C. F., Sparkes, B., Israel, S., and Ketchum, J.: New insights into the Neoproterozoic geology of the central Avalon Peninsula (Parts of NTS Map Areas 1N/6, 1N/7 and 1N/3), Eastern Newfoundland. Current Research, Newfoundland and Labrador Department of Mines and Energy Report 01, 169-189, 2001.

Olsson, J. R., Söderlund, U., Hamilton, M. A., Klausen, M. B., and Helffrich, G. R.: A late Archaean radiating dyke swarm as possible clue to the origin of the Bushveld Complex, Nature Geosci., 4, 865-869, 2011.

Paces, J. B. and Miller Jr., J. D.: Precise U-Pb ages of Duluth complex and related mafic intrusions, northeastern Minnesota: Geochronological insights to physical, petrogenetic, paleomagnetic, and tectonomagmatic processes associated with the $1.1 \mathrm{Ga}$ midcontinent rift system, J. Geophys. Res.-Sol. Ea., 98, $13997-$ 14013, 1993.

Peng, S., Babcock, L. E., and Cooper, R. A.: The Cambrian Period, in: The Geologic Time Scale 2012, vol. 2, edited by: Gradstein, F. M., Ogg, J. G., Schmitz, M. D., and Ogg, G., Elsevier, Oxford, 437-488, 2012.

Pollock, J. C., Hibbard, J. P., and Sylvester, P. J.: Early Ordovician rifting of Avalonia and birth of the Rheic Ocean: U-Pb detrital zircon constraints from Newfoundland, J. Geol. Soc. London, 166, 501-515, 2009.

Pollock, J. C., Hibbard, J. P., and van Staal, C. R.: A paleogeographical review of the peri-Gondwanan realm of the Appalachian orogen, Can. J. Earth Sci., 49, 259-288, 2012.

Rasmussen, B. and Fletcher, I. R.: Zirconolite: a new U-Pb chronometer for mafic igneous rocks, Geology, 32, 785-788, 2004.

Rayner, N., Stern, R. A., and Carr, S. D.: Grain-scale variations in trace element composition of fluid-altered zircon, Acasta Gneiss Complex, northwestern Canada, Contrib. Mineral. Petr., 148, 721-734, 2005.

Renna, M. R., Tiepolo, M., and Tribuzio, R.: In situ U-Pb geochronology of baddeleyite-zircon pairs using laser-ablation ICPMS: the case-study of quartz gabbro from Varney Nunatak (central Victoria Land, Antarctica), Eur. J. Mineral., 23, 223240, 2011.

Rioux, M., Bowring, S., Dudás, F., and Hanson, R.: Characterizing the $\mathrm{U}-\mathrm{Pb}$ systematics of baddeleyite through chemical abrasion: application of multi-step digestion methods to baddeleyite geochronology, Contrib. Mineral. Petr., 160, 777-801, 2010.

Schaltegger, U. and Davies, J. H. F. L.: Petrochronology of zircon and baddeleyite in igneous rocks: Reconstructing magmatic processes at high temporal resolution, Rev. Mineral. Geochem., 83, 297-328, 2017.

Schmitt, A. K., Chamberlain, K. R., Swapp, S. M., and Harrison, T. M.: In situ U-Pb dating of micro-baddeleyite by secondary ion mass spectrometry, Chem. Geol., 269, 386-395, 2010.

Schmitz, M. D., Bowring, S. A., and Ireland, T. R.: Evaluation of Duluth Complex anorthositic series (AS3) zircon as a U$\mathrm{Pb}$ geochronological standard: New high-precision isotope dilution thermal ionization mass spectrometry results, Geochim. Cosmochim. Ac., 67, 3665-3672, 2003. 
Söderlund, U. and Johansson, L.: A simple way to extract baddeleyite $\left(\mathrm{ZrO}_{2}\right)$, Geochem. Geophy. Geosy., 3, 1-7, https://doi.org/10.1029/2001GC000212, 2002.

Söderlund, U., Ibanez-Mejia, M., El Bahat, A., Ikenne, M., Soulaimani, A., Youbi, N., Ernst, R. E., Cousens, B., El Janati, M., and Hafid, A.: Reply to Comment on " $\mathrm{U}-\mathrm{Pb}$ baddeleyite ages and geochemistry of dolerite dykes in the Bas-Drâa inlier of the Anti-Atlas of Morocco: Newly identified 1380 Ma event in the West African Craton" by André Michard and Dominique Gasquet, Lithos, 174, 99-100, 2013.

Stacey, J. S. and Kramers, J. D.: Approximation of terrestrial lead isotope evolution by a two stage model, Earth Planet. Sc. Lett., 26, 207-221, 1975.

Steiger, R. H. and Jäger, E.: Subcommission on geochronology: convention on the use of decay constants in geo- and cosmochronology, Earth Planet. Sc. Lett., 36, 359-362, 1977.

Sun, Y., Schmitt, A. K., Pappalardo, L., and Russo, M.: Quantification of excess ${ }^{231} \mathrm{~Pa}$ in late Quaternary igneous baddeleyite, Am. Mineralogist, https://doi.org/10.2138/am-2020-7449, in press, 2020.

van Staal, C. R. and Barr, S. M.: Lithospheric architecture and tectonic evolution of the Canadian Appalachians and associated Atlantic margin, chap. 2, in: Tectonic Styles in Canada: the Lithoprobe Perspective, edited by: Percival, J. A., Cook, F. A., and Clowes, R. M., Geological Association of Canada Special Paper, 49, 41-95, 2012.

Vermeesch, P.: IsoplotR: a free and open toolbox for geochronology, Geosci. Front., 9, 1479-1493, https://doi.org/10.1016/j.gsf.2018.04.001, 2018.

Wall, C. J. and Scoates, J. S.: High-precision U-Pb zirconbaddeleyite dating of the J-M reef platinum group element deposit in the Stillwater Complex, Montana (USA), Econ. Geol., 111, 771-782, 2016.

Watson, E. B., Cherniak, D. J., Hanchar, J. M., Harrison, T. M., and Wark, D. A.: The incorporation of Pb into zircon, Chem. Geol., 141, 19-31, 1997.
White, L. F., Černok, A., Darling, J. R., Whitehouse, M. J., Joy, K. H., Cayron, C., Dunlop, J., Tait, K. T., and Anand, M.: Evidence of extensive lunar crust formation in impact melt sheets 4,330 Myr ago, Nat. Astron., in press, https://doi.org/10.1038/s41550020-1092-5, 2020.

White, L. F., Tait, K. T., Kamo, S. L., Moser, D. E., and Darling, J. R.: Highly accurate dating of micrometre-scale baddeleyite domains through combined focused ion beam extraction and $\mathrm{U}-\mathrm{Pb}$ thermal ionization mass spectrometry (FIB-TIMS), Geochronology, 2, 177-186, https://doi.org/10.5194/gchron-2177-2020, 2020

Wiedenbeck, M., Hanchar, J. M., Peck, W. H., Sylvester, P., Valley, J., Whitehouse, M, Kronz, A., Morishita, Y., Nasdala, L., Fiebig, J., Franchi, I., Girard, J. P., Greenwood R.C., Hinton R., Kita N., Mason, P. R. D., Norman, M., Ogasawara, M., Piccoli, R., Rhede, D., Satoh, H., Schulz-Dobrick, B., Skar, O., Spicuzza, M. J., Terada, K., Tindle, A., Togashi, S., Vennemann, T., Xie, Q., and Zheng, Y. F.: Further characterisation of the 91500 zircon crystal, Geostand. Geoanal. Res., 28, 9-39, 2004.

Williams, H.: Appalachian orogen in Canada, Can. J. Earth Sci., 16, 792-807, 1979.

Willner, A. P., Barr, S. M., Glodny, J., Massonne, H.-J., Sudo, M., Thomson, S. N., van Staal C. R., and White, C. E.: Effects of fluid flow, cooling and deformation as recorded by ${ }^{40} \mathrm{Ar} /{ }^{39} \mathrm{Ar}$, $\mathrm{Rb}-\mathrm{Sr}$ and zircon fission track ages in very low- to low-grade metamorphic rocks in Avalonian SE Cape Breton Island (Nova Scotia, Canada), Geol. Mag., 152, 767-787, 2014.

Wingate, M. T. D. and Compston, W.: Crystal orientation effects during ion microprobe $\mathrm{U}-\mathrm{Pb}$ analysis of baddeleyite, Chem. Geol., 168, 75-97, 2000.

Wittmann, A., Kenkmann, T., Schmitt, R. T., and Stöffler, D.: Shock-metamorphosed zircon in terrestrial impact craters, Meteorit. Planet. Sci., 41, 433-454, 2006. 